\title{
THE MERCURIO GUNFLINTS: A TECHNO-TYPOLOGICAL AND CULTURAL ASSESSMENT
}

\author{
Paolo Biagi, Hon FSA, Elisabetta Starnini and Carlo Beltrame \\ Paolo Biagi, Department of Asian and North African Studies (DSAAM), Università Ca' \\ Foscari, Ca' Cappello, San Polo 2035, I-30I25 Venice, Italy. E-mail: pavelius@unive.it \\ Elisabetta Starnini, School of Humanistic Sciences, Department of Historical Studies, University of \\ Turin, Via Sant’Ottavio 20, I-IoI24 Turin, Italy. E-mail: elisabetta.starnini@unito.it \\ Carlo Beltrame, Department of Humanistic Studies (DSU), Università Ca' Foscari, Palazzo \\ Malcanton Marcorà, Dorsoduro 3484/D, I-30I23 Venice, Italy. E-mail: beltrame@unive.it
}

The discovery of the wreck of the brig Mercurio, which sank in I8I2 in the waters of the north Adriatic, is of major significance for the study of Italic Kingdom vessels from the Napoleonic era. The underwater excavations carried out in 2004-II led to the recovery of many small finds, among which are several gunflints of different size and shape. The Mercurio gunflints were produced mainly from blades using a technique in use in Britain and France, but also in the workshops of the Lessini Hills around Ceredo (Verona province, northern Italy). We suggest that the flint employed for their manufacture probably came from Monte Baldo, in the Trentino, or perhaps from the River Tagliamento, in Friuli. We can exclude the possibility that the specimens recovered from the shipwreck were made from French fint because of the typically north Italian manufacturing technique and the character of the grey Trevetiderived fint. Given the complexity of the period during which the Grado (or Pirano) battle took place, the study of even such small items can contribute to a better interpretation of the dramatic events that characterised the beginning of the nineteenth century in that part of the Mediterranean.

This paper describes and discusses a group of gunflints recovered during underwater excavations carried out in 2004-II on the I6-gun brig Mercure (later renamed the Mercurio) found in the northern Adriatic. The vessel, built for the French navy in Genoa in 1806, entered the Napoleonic Italic Kingdom fleet, based in Venice, in I809-IO. ${ }^{\mathrm{I}}$ The ship was sunk on the morning of 22 February I 12 by the British brig Weasel (or Weazel) in the Grado (also known as the Pirano) battle while it was on a mission to escort the 80-gun vessel Rivoli out of the Venetian lagoon. ${ }^{2}$ The Mercurio was commanded by Lieutenant Palinucchia (or Palincucchia) and the crew consisted of ninety-two men, including five officers. ${ }^{3}$ The wreck was discovered accidentally in $200 \mathrm{I}$ at the depth of I6-I7m below sea-level, some 7 miles (IIkm) off the Punta Tagliamento, in the delta of the River Tagliamento, along the present coast of Friuli, south of the city of Lignano Sabbiadoro (fig I) ${ }^{4}$ At the time of its discovery the shipwreck was in a good

I. Beltrame 20I0, 55; 2015, 423.

2. Beltrame 2010; Russell and Cohn 2015.

3. Beltrame 2007.

4. Beltrame and Gaddi 2002; Beltrame 2007; 2009; 2014. Its precise geographic location is $45^{\circ} 33^{\prime} \mathrm{N}-13^{\circ}$ II'E. 


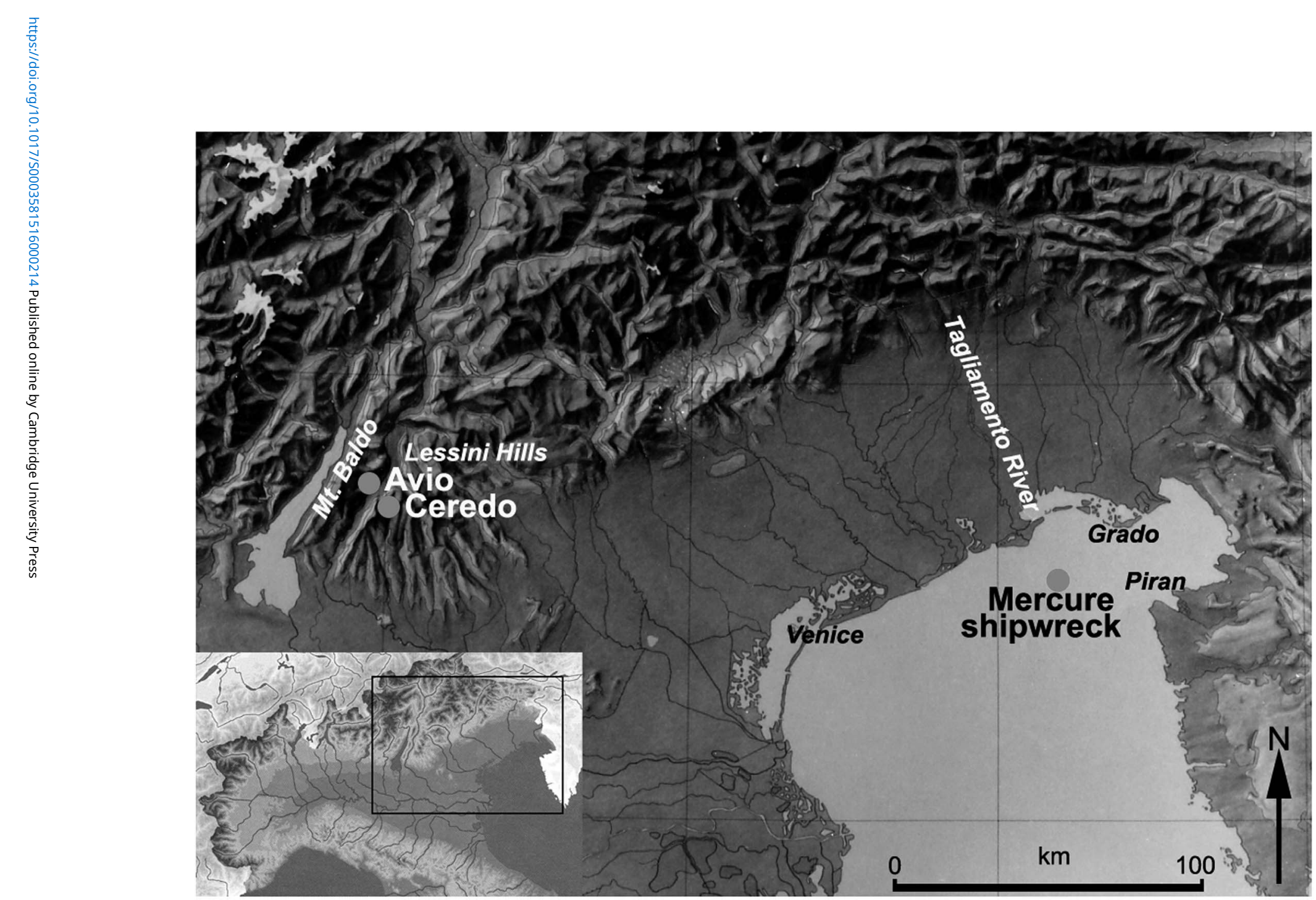

Fig I. Location of the Mercurio shipwreck and of the flint sources and workshops discussed in the text. Drawing: E Starnini 


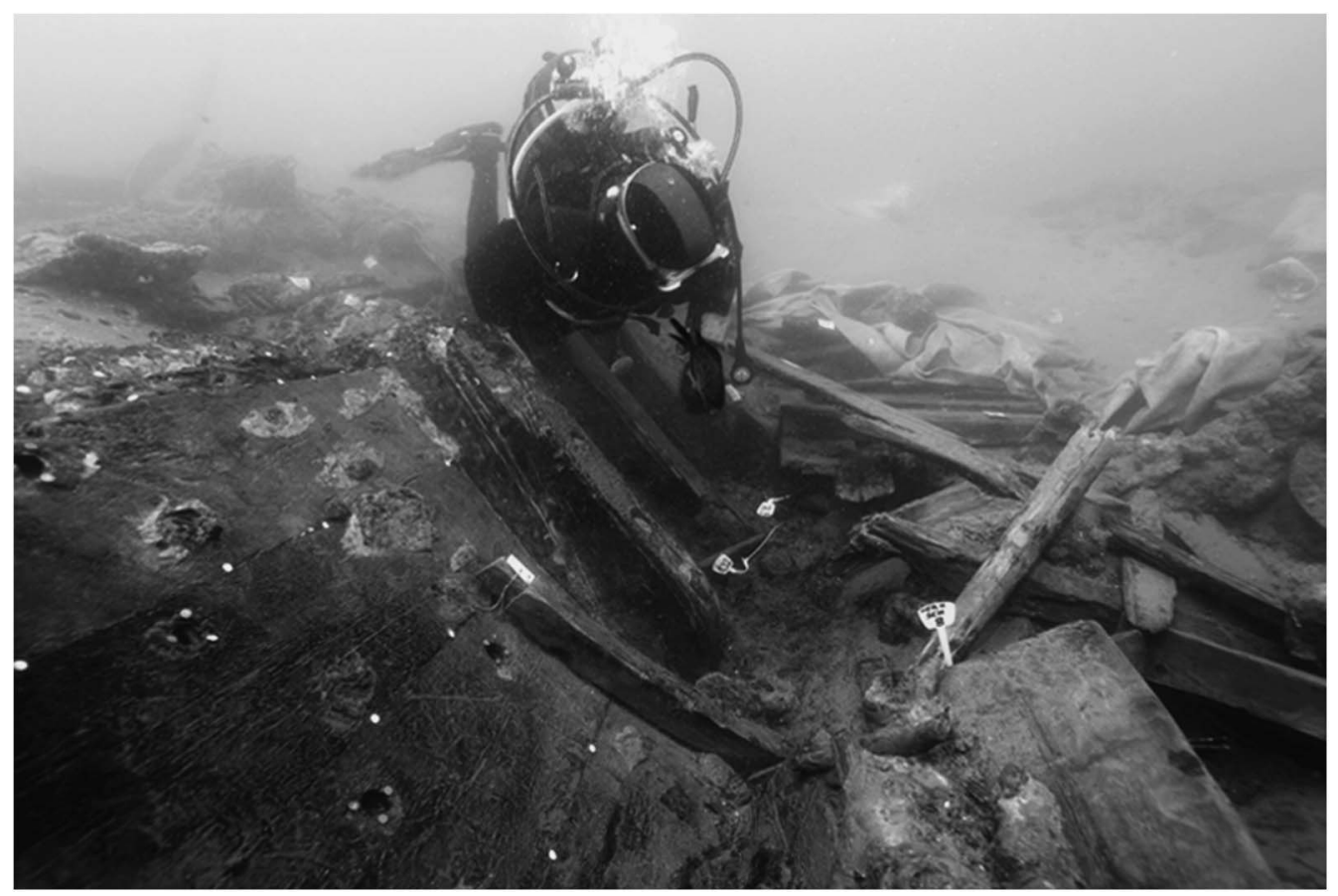

Fig 2. The Mercurio: the left-hand side of the hull in the prow area. Photograph: S Caressa

state of preservation (fig 2), protruding from the sand on the seabed, with only a tumulus of concretions and some iron carronades around it. Although split in two main parts, lying some $70 \mathrm{~m}$ apart (excavation Zones A and B respectively), ${ }^{5}$ the Mercurio is so far one of the bestpreserved underwater wrecks of this period in the Mediterranean Sea.

As well as the remains of seven crewmen, ranging in age from sixteen to forty-five, ${ }^{6}$ some 900 objects were brought to light during excavations carried out by Ca' Foscari University, Venice. ${ }^{7}$ These included a large number of firearms: one bronze swivel gun, eight 24-pounder iron carronades, two 8-pounder iron guns, five pistols (pistolet de bord) model I786, made in Tulle, ${ }^{8}$ one musket (mousqueton de hussard) model I786, probably made in Brescia, ${ }^{9}$ one musket butt plate, three plate locks of small arms, some iron cannon balls and hundreds of lead musket balls, as well as the gunflints that are the subject of this paper. The gunflints come from the bow (Zone A, squares 8 and 9), where the pistols, musket and human remains were found. ${ }^{\mathrm{IO}}$ Although the gunflints could be used for artillery, none of the

\section{Beltrame 20I0, fig 2.}

6. Bertoldi et al 2014. Among the human remains are most probably those of the commissioner, an administrative officer some 40 years old, who was identified thanks to specific elements of his uniform among which are metal buttons. The taphonomic and anthropological analyses of the human remains are still in progress.

7. Beltrame 2015 .

8. S Donadel, pers comm, I2 Nov 20I5; see <http://www.lapistole.com/I786\%20marine.html> (accessed I2 Apr 20I6).

9. S Donadel, pers comm, I2 Nov 2015.

IO. Beltrame 2014, 63. 
carronades of the An XIII model or the 1786 model guns found aboard the Mercurio were equipped with a gunlock. ${ }^{\text {II }}$ However, the brass fragment (see fig 9, bottom) is clearly a piece of a gunlock produced in Paris, suggesting that there were cannons on board the Mercurio that were equipped with this technological innovation.

The study of gunflints from shipwrecks has slowly gained ground during the last fifteen years. ${ }^{{ }^{2}}$ Nevertheless papers on this specific topic are still few, despite their importance for the recognition of gunflint production centres, their raw material provenance, the trajectories of military supply and trade routes, and their exploitation and use by crew members of different nationalities. Locating the raw material sources for the manufacture of gunflints, their production methods and typological analysis are all important steps in the study of the weaponry utilised on Italic Kingdom Napoleonic vessels, which depended also on the nationality of the crew members (we know that Dalmatian, Istrian, Venetian, Genoese and French sailors served on the Mercurio). Problems that could hamper such studies derive from their deposition, patination and state of preservation in Mediterranean seawaters, ${ }^{13}$ as well as the occasional presence of concretions. ${ }^{\mathrm{I4}}$

The study of gunflints has so far been concerned mainly with British, ${ }^{15}$ French, ${ }^{16}$ Danish, ${ }^{17}$ Dutch, ${ }^{18}$ East European, ${ }^{19}$ South Balkan ${ }^{20}$ and American assemblages, ${ }^{21}$ although the provenance of the raw material sources employed for their manufacture is sometimes difficult to assess. ${ }^{22}$ By contrast, insufficient attention has been paid to the Lessini Hills (Ceredo) and Monte Baldo (Avio) production centres, ${ }^{23}$ the most important suppliers of the imperial army of the Habsburg monarchy. ${ }^{24}$ Millions of pieces were produced and exported every year from the workshops located around Ceredo (Verona) and Avio (Trento) that were active mainly during the eighteenth and early nineteenth centuries. ${ }^{25}$

A manuscript written in 1820 by Dr Bourgoin reports: Dans le Veronais on traitait des silex de Montebaldo, lequel était grisâtre, d'une pâte assez fine e dure, ressemblant à l'agate; les pierres à fusil ne pouvaient fabriquer qu'au rouet et leur prix était trop élevé pour pouvoir être adoptées dans l'usage général ('In the Verona region they also work flint from Montebaldo, which is greyish, of very fine and hard texture, similar to agate; the gunflints can be produced only by hammering, and their price is too high for them to be adopted for general use'). Some half a century earlier, General J-J Gassendi had observed that Veronese gunflints were more than twice as large as French specimens and their quality inferior. ${ }^{26}$ According to J Emy,

II. Boudriot and Berti I98I, 46; Boudriot I992, I00-I.

I2. Cumming 2002; Bingeman 2004; Ballin 2014a.

I3. Ballin 20I4a.

I4. Ballin 20I4b.

I5. Whittaker 200I.

I6. Schleicher 1927.

I7. Ballin 20I4c.

I8. Witthoft 1966.

I9. Ginter 2009; Ballin 2013a.

20. Evans I887.

2I. Austin 20II.

22. Durst 2009.

23. Von Born I790; Orsi I 886.

24. Woodall et al 1997, 17.

25. Chelidonio I992; 2003, I26.

26. Emy I978, II4. 
author of the seminal volume on gunflint production from Verona province, ${ }^{27}$ they were roughly made, and their shape was irregular. ${ }^{28}$

Mitchell was the first to describe British gunflint manufacturing ${ }^{29}$ followed some forty years later by Skertchly. ${ }^{30}$ Salmon did the same in France before the end of the century. ${ }^{3 \mathrm{I}}$ Blade gunflints were produced in both countries using similar techniques. ${ }^{32}$ Although good information was already available for gunflint manufacture from a few other European countries before the $1980{ }^{33}$ data on the topic were still very poor for the Lessini Hills gunflint workshops until the publication of the excavations carried out near Ceredo by $\mathrm{J} \mathrm{N}$ Woodall et al. ${ }^{34}$ These revealed the importance of the Ceredo production centre, as well as helping to define the different manufacturing stages and the characteristics of the final products; these are somewhat similar to those from Britain, but broader and thinner. ${ }^{35}$

\section{THE MERCURIO GUNFLINTS}

The Mercurio chipped stone assemblage discussed in this paper consists of eighty-five gunflints (figs 3 to 7; tables I and 2). They were all recovered from excavation Zone A, squares 8 and 9 (fig 8). Nine specimens were retrieved from a single concreted block together with a metal fragment of French cannon gunlock (fig 9). ${ }^{36}$

All the gunflints except one are obtained from black/dark-grey/bluish-grey flint, with small whitish spots or lighter grey variegations or stripes (see table 2). The precise flint source exploited for their manufacture is so far undefined. According to our present knowledge, only one Mercurio gunflint was knapped from the brown spotted Lessini flint, ${ }^{37}$ characteristic of the 'Biancone' and 'Scaglia Variegata' flint formations of the Veronese Lessini Hills and Trentino, ${ }^{38}$ whose geological location is well known. ${ }^{39}$ The remainder are more like Monte Baldo gunflints in their use of a distinctive type of greyish flint, ${ }^{40}$ the outcrops of which might be those that are described by Barbieri et al, ${ }^{4 \mathrm{I}}$ consisting of greyish spotted flint formations in the Scaglia Variegata deposits that supply nodules of 'sufficient' quality for knapping. ${ }^{42}$ Furthermore, black and dark grey flint is available from the moraines of the

27. Ibid.

28. It is important to note that, according to Emy, some black and grey gunflints were also produced in France as well as the more common honey- and amber-coloured gunflints. For example, medium- to low-quality grey flint sources exist in Treveti, near Châtillon, south west of Paris, though it was rarely utilised for the production of gunflints.

29. Mitchell 1837.

30. Skertchly 1879 .

3I. Salmon I885.

32. Barnes 1937; White 1975.

33. Emy 1978, i 12 .

34. Woodall et al I997, 25.

35. Ibid, fig 6.

36. De Vries and Martens $2007,776-7$.

37. Barfield I994.

38. Barbieri et al 2013, fig $2 \mathrm{f}$.

39. Brandl 2013.

40. Emy 1978, II4; see above.

4I. Barbieri et al 2013, figs $3 \mathrm{~d}$ and $3 \mathrm{f}$.

42. Ibid. 

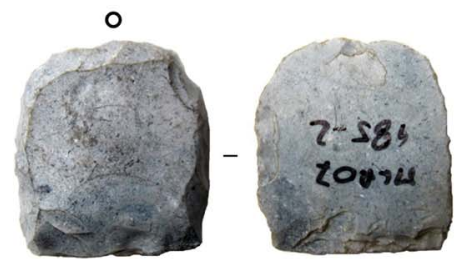

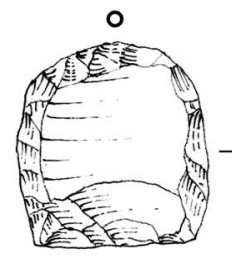

1
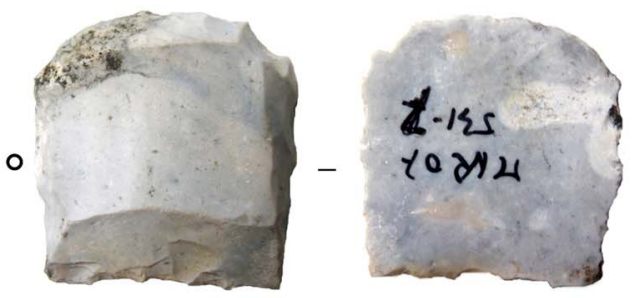

2

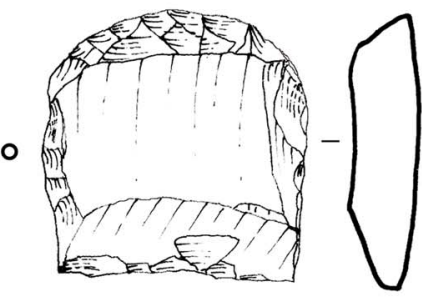

0 $\mathrm{cm} \quad 3$
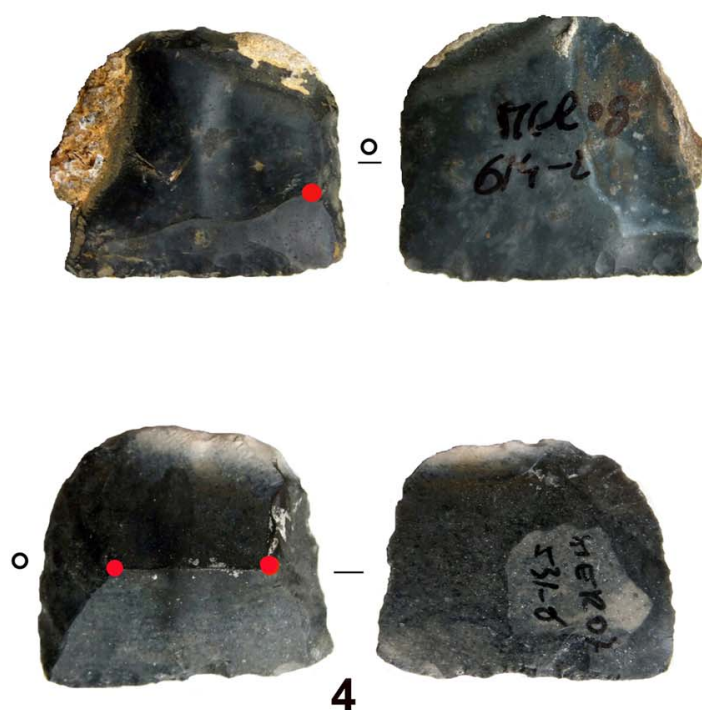
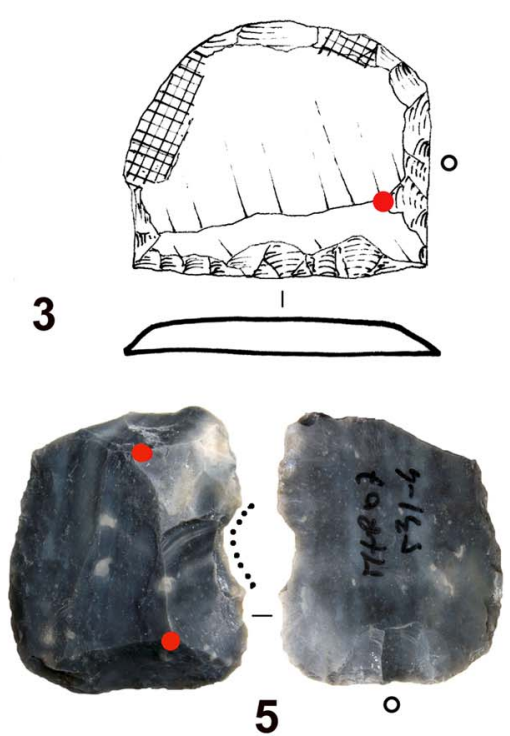

Fig 3. D-shaped gunflints of Class I (nos I-4) and utilised gunflint of Class 3 (no. 5), with indication of the percussion bulb (black circles) and bevel arrises (red dots). Drawings: P Biagi and E Starnini; photographs: E Starnini

River Tagliamento and from the Carnic Pre-Alps, in the Friuli region of north-eastern Italy. ${ }^{43}$ These were exploited for making chipped stone tools as far back as the beginning of the Holocene. ${ }^{44}$

43. Dal Santo 2004.

44. Ferrari and Pessina 1996. 

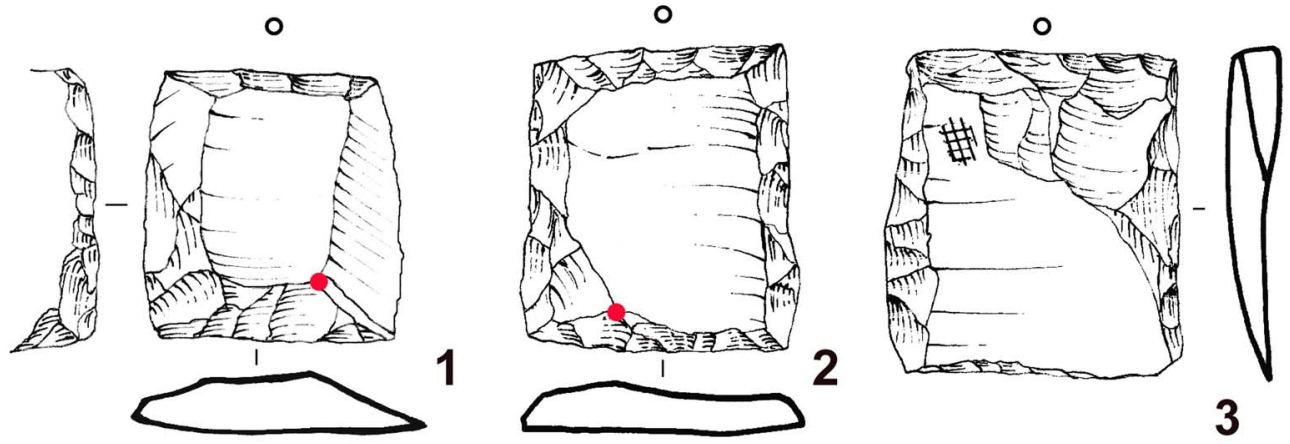

O
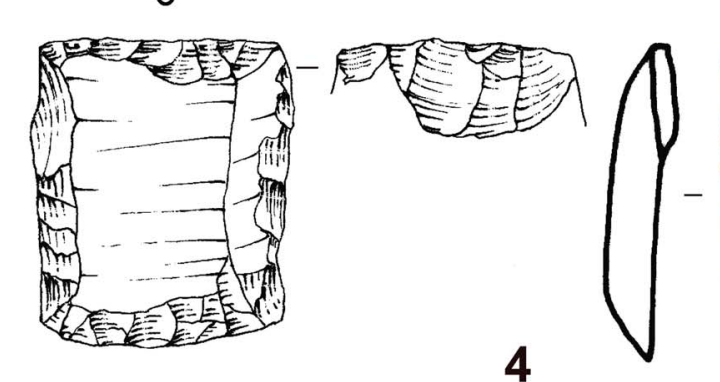

0
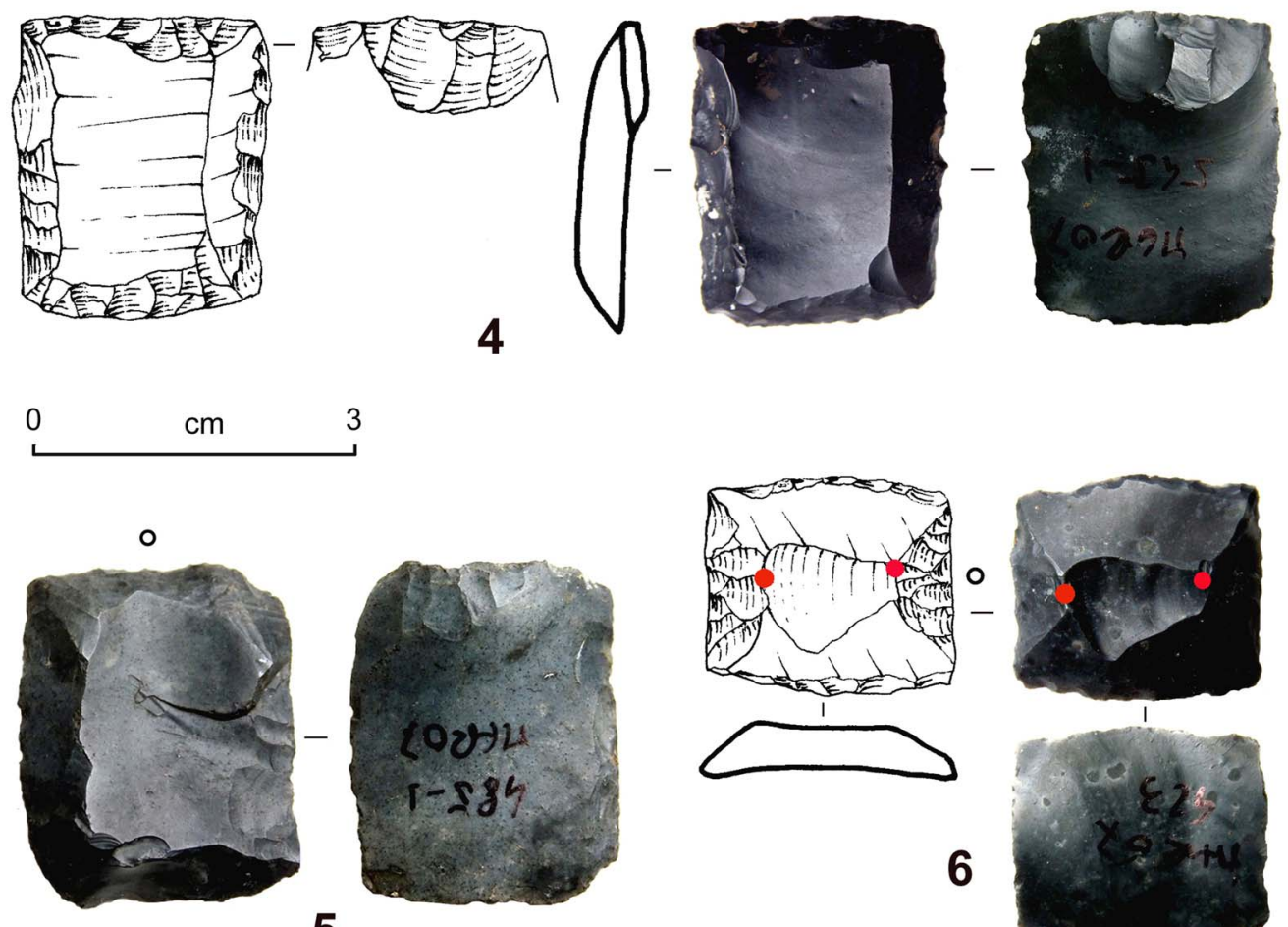

5
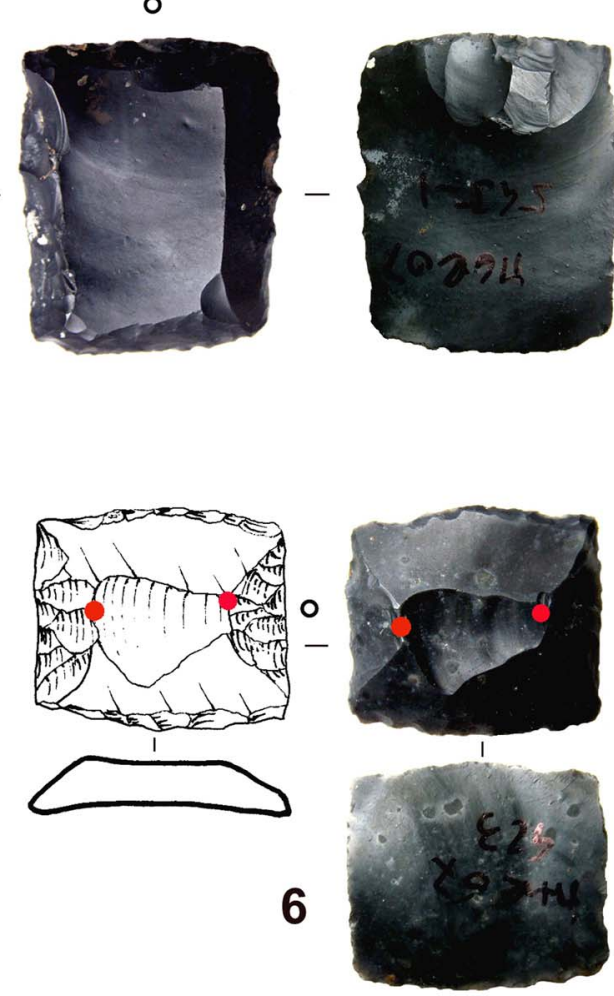

Fig 4. Gunflints of Class 2 (nos I-5) and Class 3 (no. 6), with indication of the percussion bulb (black circles) and bevel arrises (red dots). Drawings: P Biagi and E Starnini; photographs: E Starnini

In describing the morphology of the Mercurio gunflints (tables I and 2) we have followed the typology of Seymour Joly de Lotbiniere ${ }^{45}$ who subdivided them into four main classes: I) D-shaped; 2) squared; 3) squared with two dorsal arrises; and 4) squared with only one arris. ${ }^{46}$ The terminology adopted in this paper is that proposed

45. De Lotbiniere 1984.

46. Ibid, 206. 

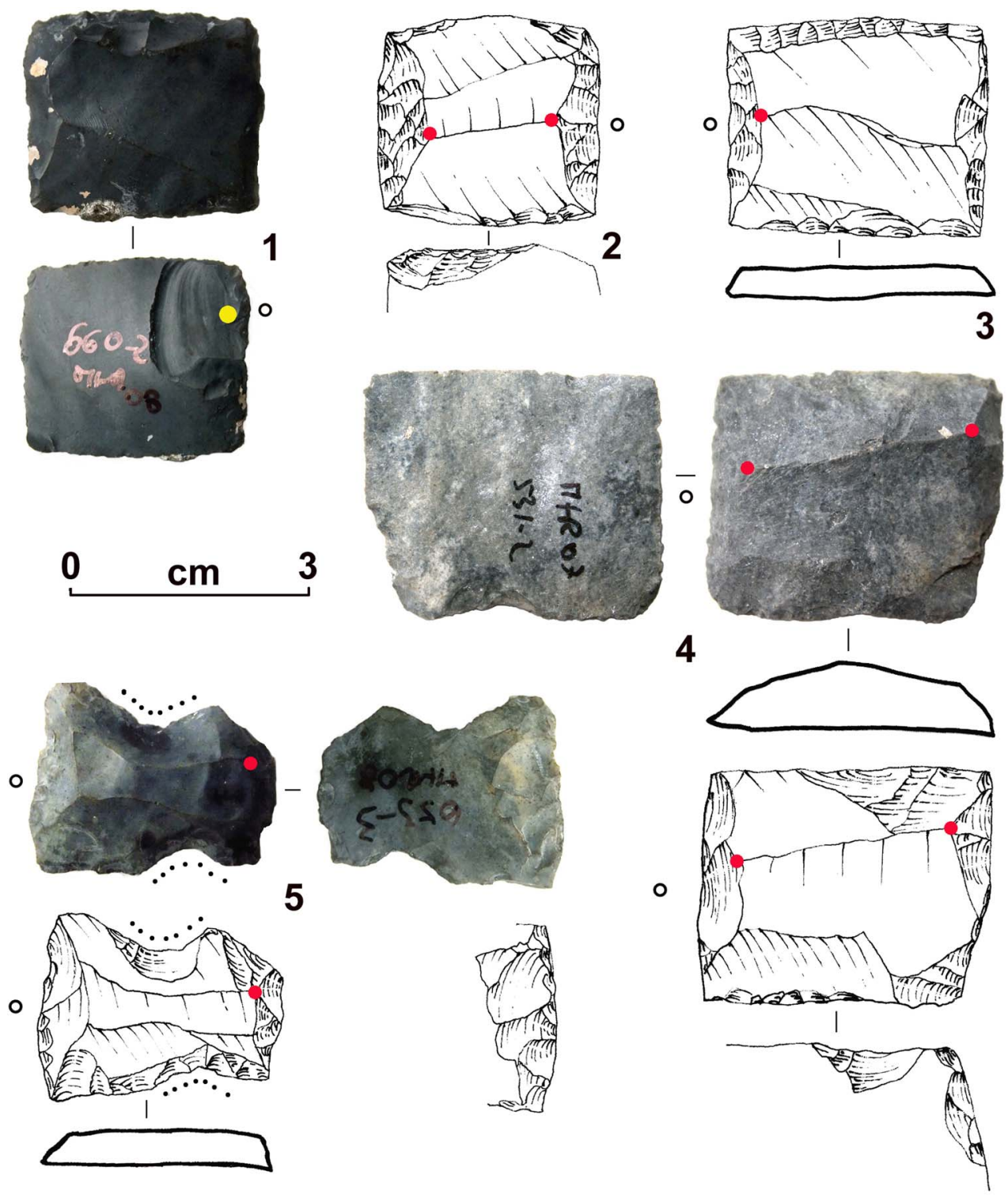

Fig 5. Gunflints of Class 2 (no. I), Class 3 (nos 2, 4 and 5) and Class 4 (no. 3), with indication of the percussion bulb (black circles), bevel arrises (red dots) and ventral bulbar scar (yellow dot). Drawings: P Biagi and E Starnini; photographs:

E Starnini

by $\mathrm{T}$ B Ballin, ${ }^{47}$ while the description of the retouching on the leading edge, heel and sides follows that introduced by $\mathrm{G}$ Laplace ${ }^{48}$ for prehistoric chipped stone tools. Four Mercurio pieces have been attributed to Class I, thirteen to Class 2, seventeen to Class 3 and forty-six

47. Ballin 20I2, II7.

48. Laplace 1964. 

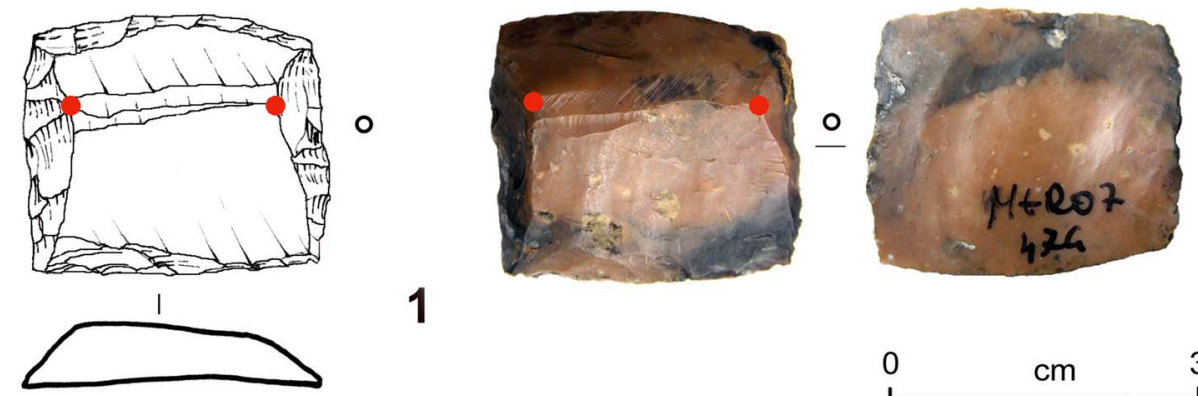

1
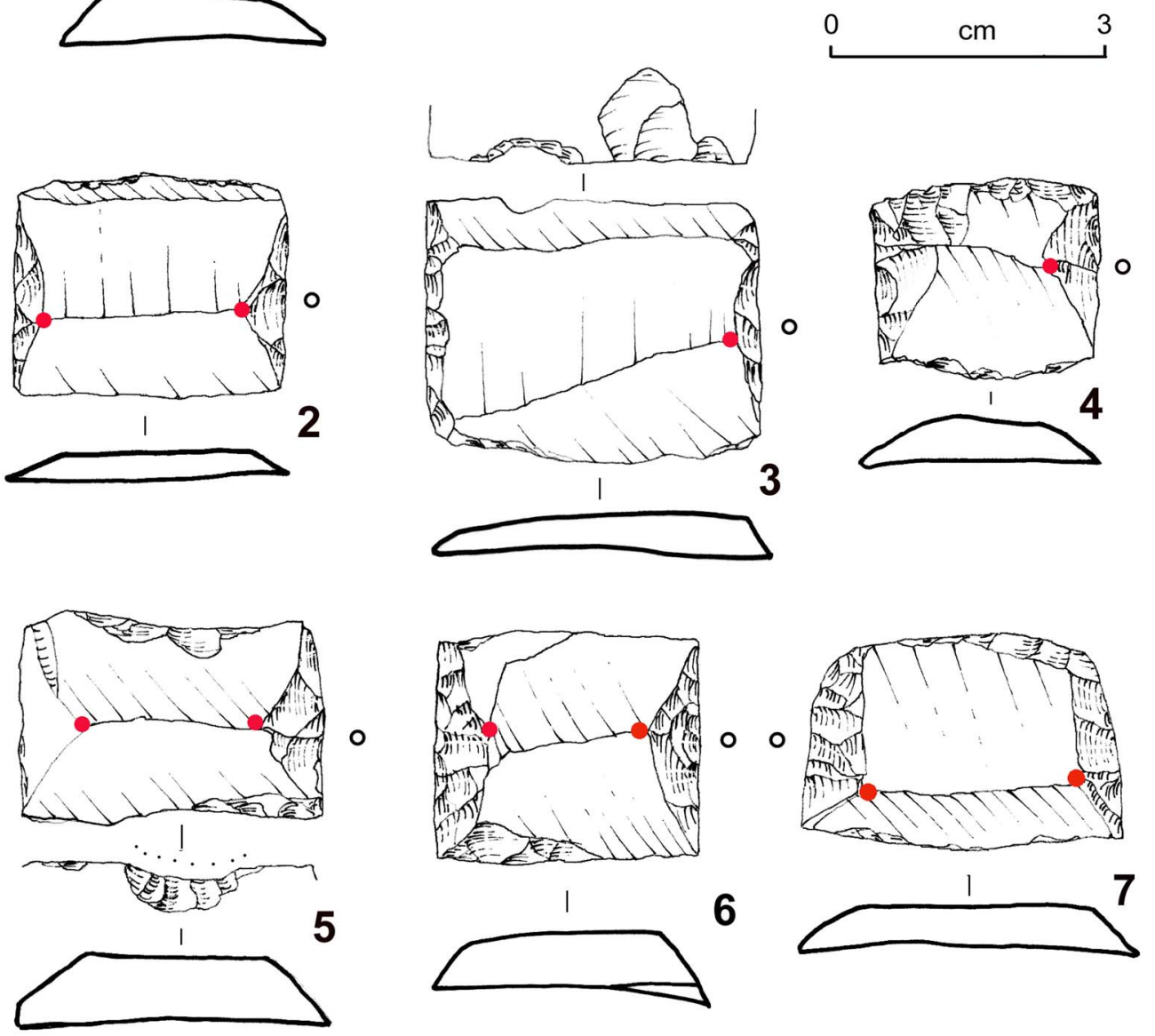

Fig 6. Gunflints of Class 4 (nos $\mathrm{I}-7$ ), with indication of the percussion bulb (black circles) and bevel arrises (red dots). Drawings: P Biagi and E Starnini; photographs: E Starnini

to Class 4 . Four have been assigned to Class 3 or 4 because they were found still inserted in their lead sheath, and thus it has been impossible to observe their entire shape and study them in detail.

The typology, number of complete tools and high percentage of medial pieces retrieved from the Mercurio suggest that most specimens (85 to 92 per cent) were obtained from blades that were long, wide and thin. The presence of one or two small dorsal scars is typical of a knapping technique involving hard hammering 

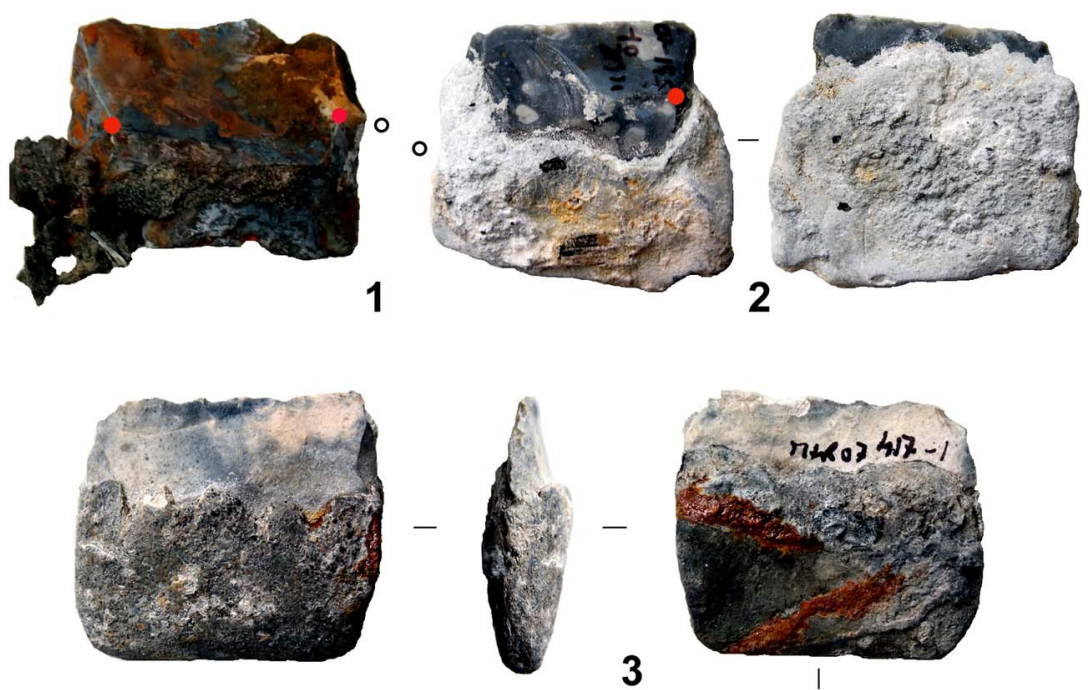

3
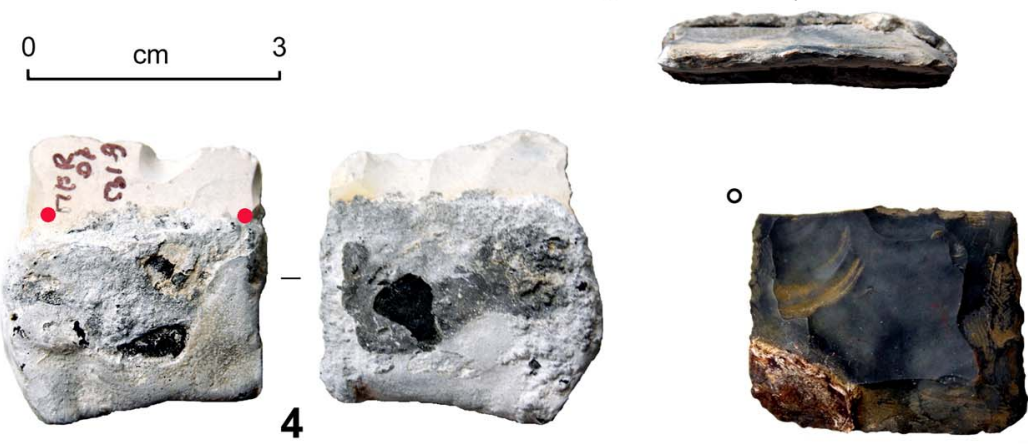

5
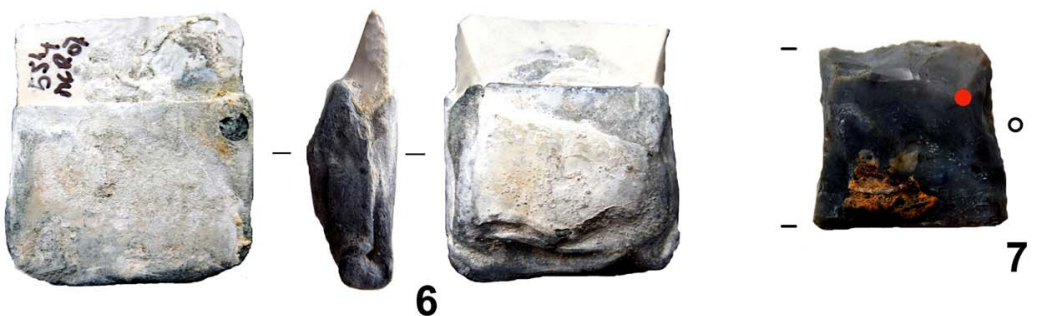

Fig 7. Gunflints of Class 4 (nos I, 5 and 7) and Class 3 or 4, partly covered by a lead sheath (nos 2-4 and 6), with indication of the percussion bulb (black circles) and bevel arrises (red dots). Photographs: E Starnini

when the blade was positioned on a stake (fig IO, nos I and 2). ${ }^{49}$ The same can be said for the presence of three specimens with wide ventral lenticular bulbar scars (fig 5, no. I; fig IO, no. 3) consequent on violent hard-hammering detachment with a metal-pointed tool. ${ }^{50}$ Only seven to fourteen specimens are obtained from flakes (fig 7, no. 5).

49. Emy I978, pl ix; Woodall and Chelidonio 2006, 224.

50. Emy I978, pl iv. 


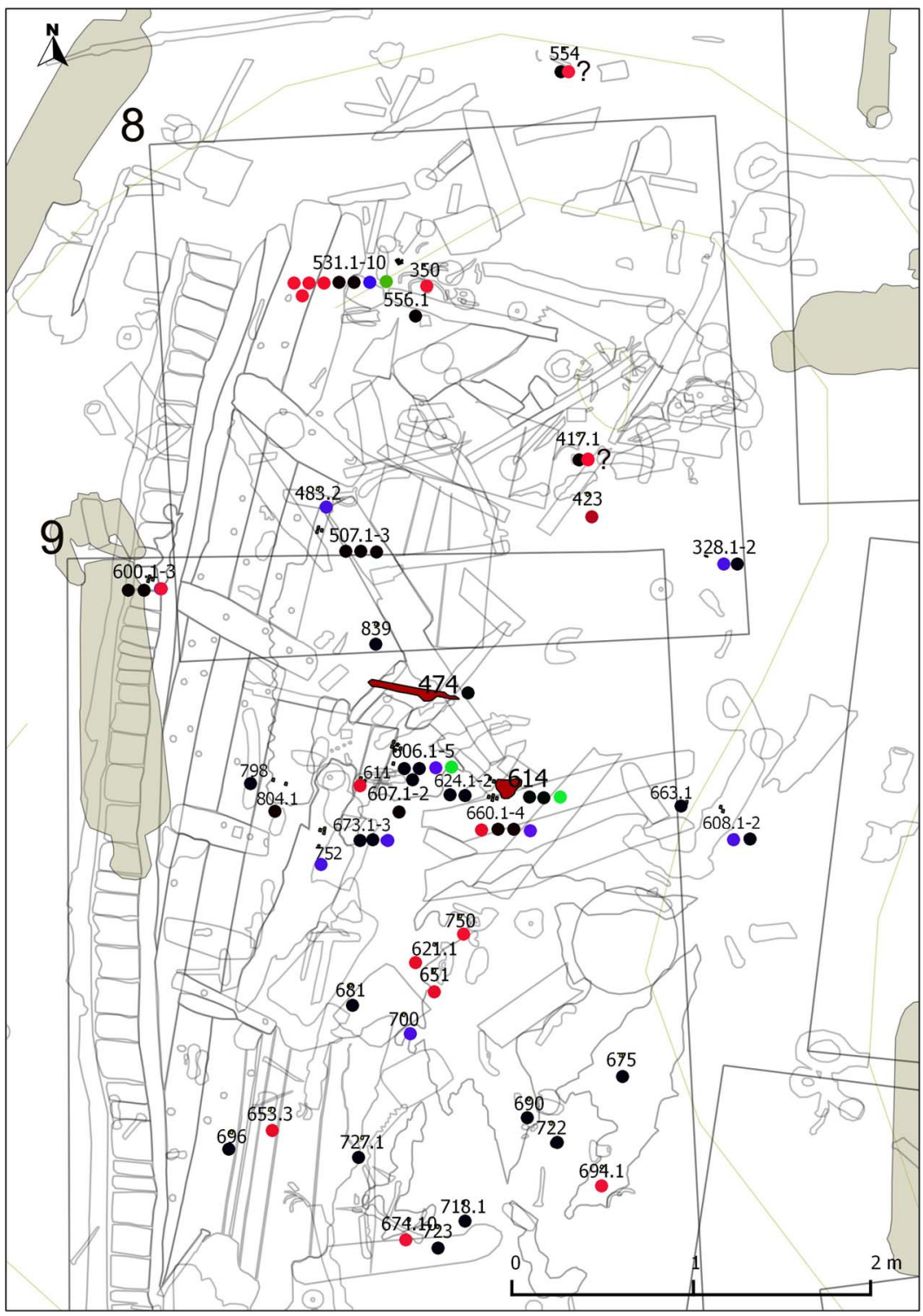

Fig 8. Distribution of the gunflints recovered from excavation Zone A, squares 8 and 9. Class I: green dot; Class 2: red dot; Class 3: blue dot; Class 4: black dot; Class 3 or 4: black and red dots. Drawing: S Manfio

Just a few pieces show an invasive thinning retouch to remove the bulb at the proximal ventral end (fig 4 , nos 4 and 5 ; fig 5, no. 5). Most of the gunflints look new and unused, except for a few specimens with traces of wear (see table 2) or a chipped leading edge (fig 3, nos I and 2; fig 5 , no. 4). Only two have a notch at the centre of the leading edge (fig 3 , no. 5 ; fig Io, no. 4). Two butterfly-shaped specimens with evident traces of use, in the form of notches along both sides, might have been reutilised as fire flints (fig 5, no. 5). 


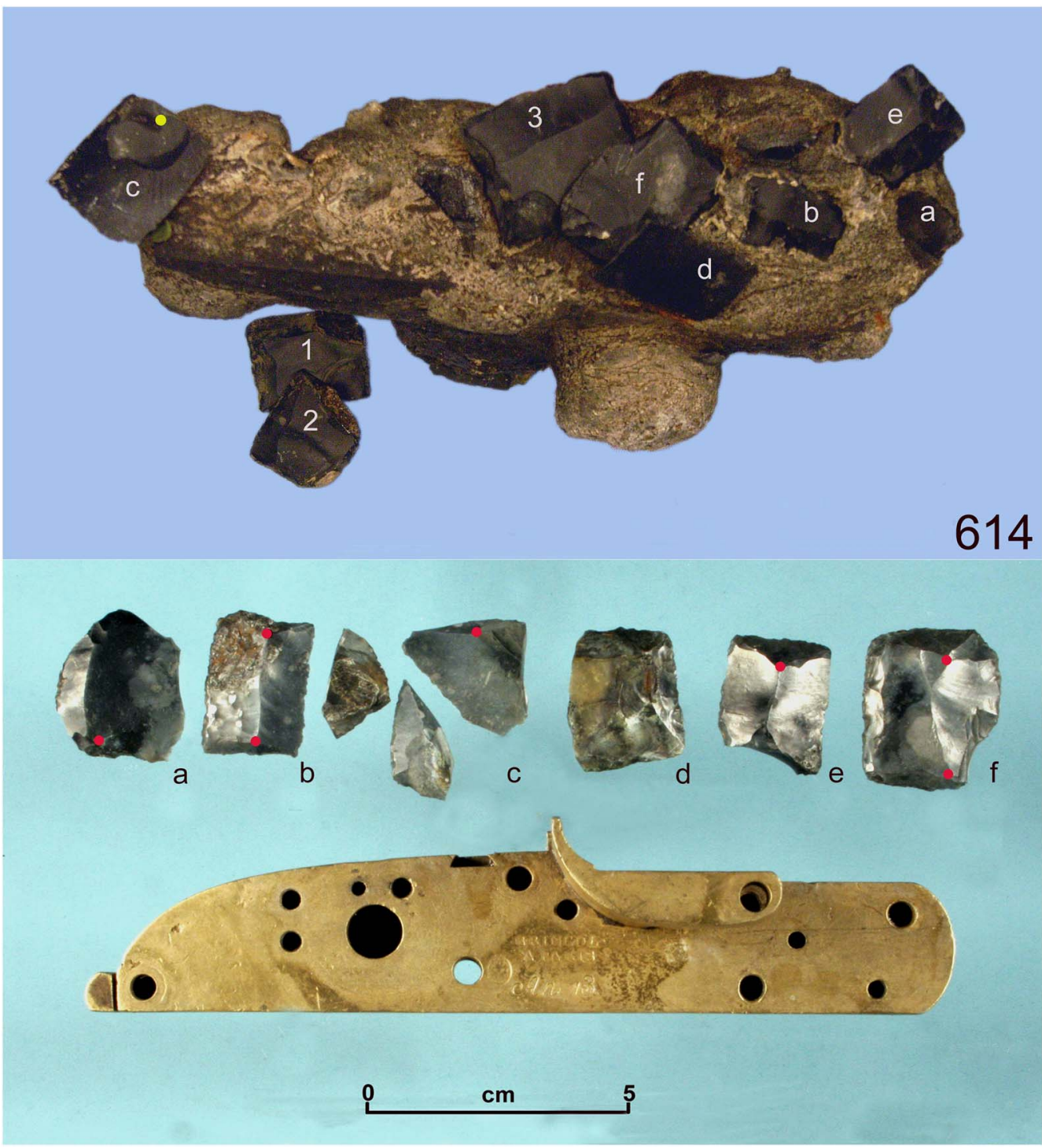

Fig 9. Concreted block containing nine gunflints and a fragment of a gunlock (6I4) before and after restoration; bevel arrises (red dots) and ventral bulbar scar (yellow dot); numbers as from tables I and 2. Photographs: C Beltrame

All the gunflints have been measured by orientating the piece according to its original blank axis. ${ }^{5 \mathrm{I}}$ The dimensional analysis, exemplified by the length/width and length/thickness diagrams (fig II), show that the Mercurio samples consist not only of different types,

5I. This is a form of measuring commonly used for prehistoric chipped stone tools. This means that, in most of the cases considered from this assemblage, the length corresponds to the gunflint's width and the width to the gunflint's length, if a gunflint's length is defined as the axis running from its heal/rear to its leading edge/front. 

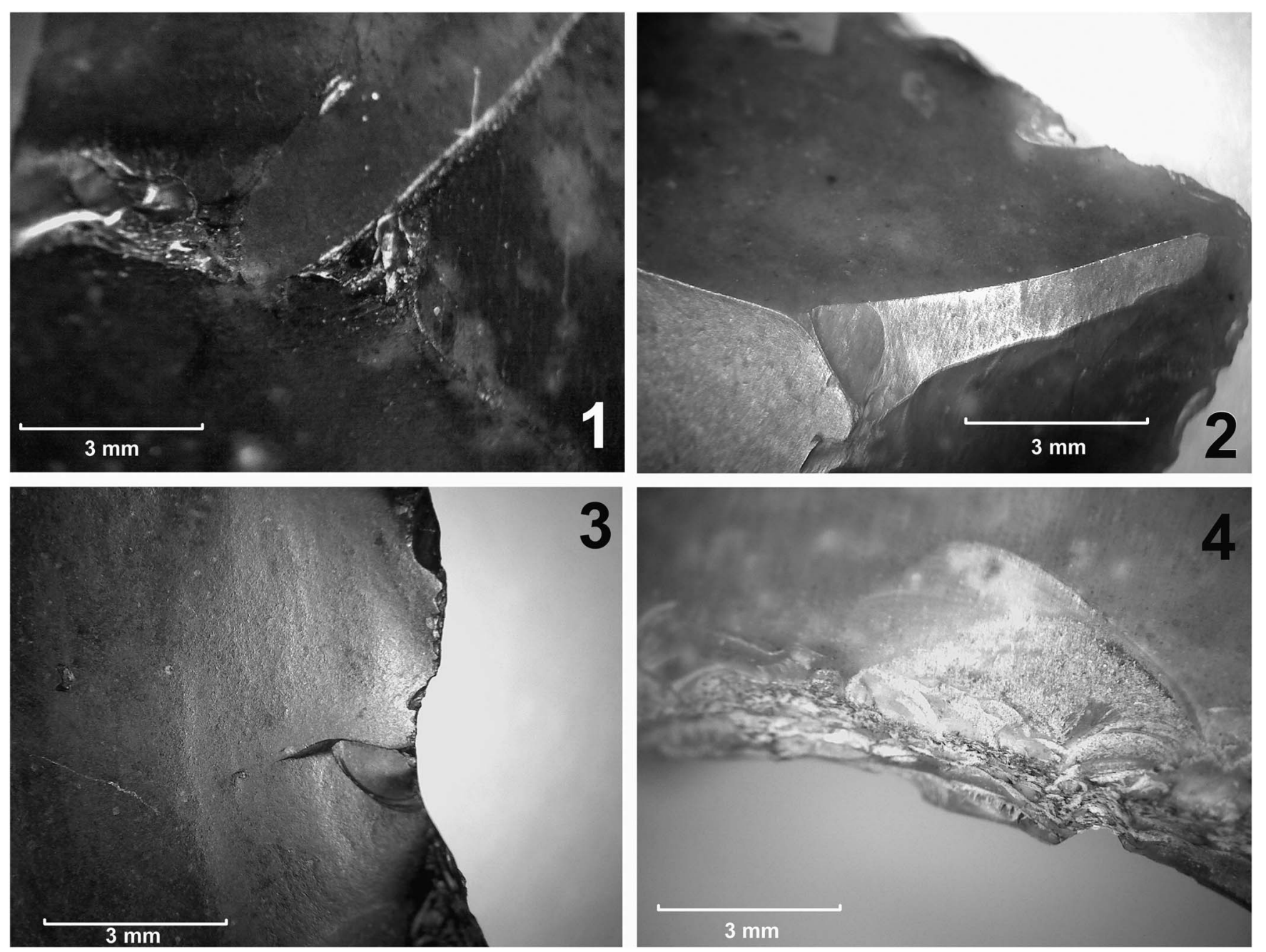

Fig Io. Proximal, right bevel arris of gunflint 609 (no. I); proximal, left bevel arris of gunflint 663-I (no. 2); ventral bulbar scar of gunflint 68I (no. 3); and utilisation traces of gunflint 624-I (no. 4). Micro-photographs: E Starnini 

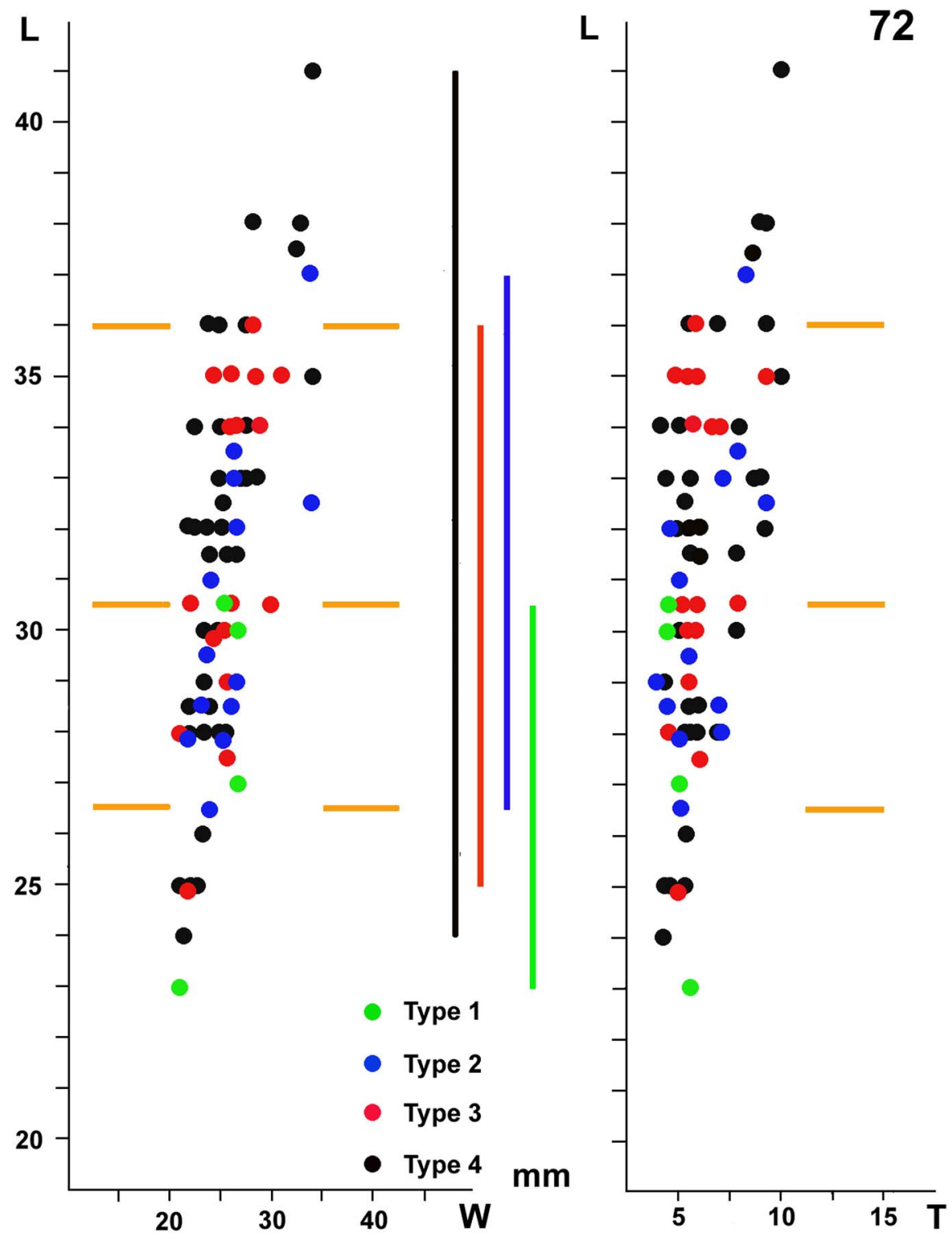

Fig II. Length/width (left) and length/thickness (right) diagrams of the seventytwo complete gunflints. The colours indicate the four different classes (I to 4) into which they have been subdivided. The vertical lines represent the maximum and minimum dimensions of the different classes throughout the assemblage. Drawing: P Biagi

but also that their dimensions differ, spanning 23 to $4 \mathrm{Imm}$ in length, $2 \mathrm{I}$ to $34 \mathrm{~mm}$ in width and 4 to Iomm in thickness. Their average size differs from that of both French and British types. ${ }^{52} \mathrm{~A}$ closer comparison is with rectangular specimens from 52. Ballin 20r3b, 8 . 
Andalucia. ${ }^{53}$ The variable size and shape suggest that they were employed in different types of firearm. ${ }^{54}$ Fortunately, the lead sheath into which four military gunflints of Class 3 or 4 are inserted has been preserved (fig 7, nos 2-4 and 6). ${ }^{55}$ Three of the leaded specimens are covered by a whitish patina that rarely occurs on other samples from the same assemblage (fig $7, \operatorname{nos} 3,4$ and 6).

Two of the Mercurio gunflints (fig 3, nos 3 and 4) are similar in material and shape to some pieces from Castle Neugebäude, on the outskirts of Vienna, where an impressive cache of gunflints, chronologically attributed to the siege of Vienna by Napoleon in 1805 , has been recovered. ${ }^{56}$ They have been attributed to the Lessini Hills manufacture area.

\section{DISCUSSION}

The gunflints excavated from the bow (excavation Zone A) of the Mercurio represent the only assemblage of this type ever studied from a shipwreck of the Napoleonic-era Italic Kingdom. The scope of the present analysis is to shed some light on a few important topics, among which are: I) typology; 2) manufacture; 3) raw material provenance and circulation; and 4) the function of the specimens. Our conclusions for each of these points is briefly summarised below.

I) The tools have been described according to well-established typologies to enable comparison with other assemblages with similar characteristics in the future. Although not exactly identical, a few specimens recall D-shaped French types (fig 3, nos I-4). ${ }^{57}$ The typological and dimensional characteristics of all the other specimens show that they were undoubtedly produced from north Italian production centres, most probably located around Avio in Monte Baldo (Trentino), for use in military weaponry.

2) They have been manufactured according to a technique well known from Britain, France and the Lessini Hills (Verona), ${ }^{58}$ in which the gunflints were produced from segments of blade that were long, wide and thin. While the British knappers (from Brandon, for example ${ }^{59}$ ) were capable of obtaining four to five specimens from each blade, ${ }^{60}$ the north Italian knappers produced only one (or two?) pieces per blade using the same knapping technique. The Italian products were made from a lower-quality flint, sometimes of irregular shape. ${ }^{61}$ Although most of the Mercurio specimens were obtained from the central part of the blade, the bulb of the proximal pieces is always absent, or removed, or thinned by a ventral, flat, invasive retouch (see fig 4, nos 4 and 5). A few pieces show a characteristic lenticular bulbar scar on the ventral surface due to violent hard percussion with a metal hammer (see fig 5, no. I),

53. Roncal Los Arcos et al 1996.

54. See Emy 1978, I70-I; Whittaker 200I, fig I.

55. Emy 1978, 346.

56. Penz and Trnka 2004, fig IIc.

57. Ballin 2013b, fig 3 .

58. Chelidonio 1992; 2013.

59. Lovett 1877 .

60. Skertchly I879, fig I9.

6I. See Emy 1978. 
and one or two dorsal scars at the edge of the arrises. These latter are typical of the manufacturing technique of the British, French and north Italian knappers.

3) The precise location of the flint source is uncertain, though it is undoubtedly from somewhere in north-eastern Italy. Only one specimen is probably made from Lessinian, Scaglia Variegata brown flint (fig 6, no. I). ${ }^{62}$ All the other Mercurio gunflints have been obtained from grey and black flint, similar to that employed in the Lessini Hills and Avio workshops, whose provenance is most probably to be found within the Monte Baldo Scaglia Variegata formation or as naturally transported nodules in the Friuli Tagliamento moraines. The flint, although varying in colour and texture within the same geological formation, is easy to recognise because of its vitreous appearance and the presence of many small, lighter or white spots all over its surface. The Avio workshop is the most likely source of the Mercurio gunflints, a view supported by historical sources. ${ }^{63}$ Gunflint workshops are reported to have been active around Avio until I8I9, and the remains of gunflint workshops have been recognised at Pra di Stua. ${ }^{6}$ Production here seems to have ceased because of the lower quality of flint supplied by the local outcrops. ${ }^{65}$

4) The presence of different types of weapons and of crew members of several different nationalities on board the brig supports the idea that the Mercurio gunflints were used to arm a wide variety of firearms, probably produced from different countries, although the arms retrieved from excavation do not bear this out. The gunflint assemblage so far recovered during excavation is small compared to the quantity that was probably needed to supply such vessels during complex war operations, which probably carried several barrels of ammunition. ${ }^{66}$ It is difficult to understand why north Italian gunflints made from lower-quality flint were used on a Napoleonic vessel moving across insecure waters, and fighting against a very difficult enemy whose weaponry was undoubtedly superior to that of the Mercurio.

\section{CONCLUSION}

The small chipped stone assemblage of Mercurio gunflints contributes to a better understanding of the weaponry used on an early nineteenth-century ship, a topic still undeveloped in present-day archaeology. ${ }^{67}$ Furthermore it opens new perspectives on the north Italian, Veronese and Trentino gunflint industry whose products, though mostly intended to supply the Austrian imperial army, was undoubtedly utilised also on Napoleonic vessels of this period. The reason why north Italian gunflints were used on the Mercurio, instead of superior-quality, longer-lasting French 'du Berry' gunflints that might guarantee better results in case of a battle, ${ }^{68}$ is difficult to explain. Further reading and knowledge of the historical sources on gunflint commerce and the provenance of the military supplies of the Italic Kingdom navy, and the political reasons behind them, is greatly needed.

62. Barbieri et al 2013.

63. See Emy 1978, i I4.

64. G Trnka, pers comm, I8 Dec 2015.

65. Chelidonio I987, I22.

66. Emy 1978, 226.

67. Ballin 20I4b.

68. Emy 1978, I49. 
Table I. Class attribution and retouch characteristics of the Mercurio gunflints

\begin{tabular}{|c|c|c|c|c|c|c|c|c|}
\hline $\begin{array}{l}\text { Year of } \\
\text { excavation }\end{array}$ & $\begin{array}{l}\text { Inventory } \\
\text { no. }\end{array}$ & Class & $\begin{array}{l}\text { Leading edge } \\
\text { retouch }\end{array}$ & $\begin{array}{l}\text { Heel } \\
\text { retouch }\end{array}$ & $\begin{array}{l}\text { Right side } \\
\text { retouch }\end{array}$ & $\begin{array}{l}\text { Left side } \\
\text { retouch }\end{array}$ & $\begin{array}{l}\text { Demicone from } \\
\text { segmentation }\end{array}$ & Figure \\
\hline 2006 & $328-I$ & 4 & Simple, marginal, direct & Damaged & Bulbar end & Simple, deep, inverse & None & \\
\hline 2006 & $328-2$ & 2 & Simple, marginal, direct & Bulbar end & Simple, deep, direct & Simple, deep, direct & None & Fig 4 , no. 3 \\
\hline 2006 & 350 & 3 & $\begin{array}{l}\text { Simple, marginal, } \\
\text { inverse }\end{array}$ & $\begin{array}{l}\text { Simple, deep, direct, } \\
\text { partial }\end{array}$ & $\begin{array}{l}\text { Semi-abrupt, deep, } \\
\text { direct }\end{array}$ & Damaged & Left bevel arris & \\
\hline 2007 & $4 \mathrm{I} 7-\mathrm{I}$ & 3 or 4 ? & Small, inverse breaks & Lead sheath & Lead sheath & Lead sheath & Not determinable & Fig 7, no. 3 \\
\hline 2007 & 423 & 3 & Simple, marginal, direct & $\begin{array}{l}\text { Simple, marginal, } \\
\text { direct }\end{array}$ & Flat, invasive, direct & Flat, invasive, direct & Right and left bevel arrises & Fig 4 , no. 6 \\
\hline 2007 & 474 & 4 & Simple, marginal, direct & $\begin{array}{l}\text { Simple, marginal, } \\
\text { direct }\end{array}$ & $\begin{array}{l}\text { Simple, marginal, } \\
\text { direct }\end{array}$ & $\begin{array}{l}\text { Semi-abrupt, deep, } \\
\text { direct }\end{array}$ & Right and left bevel arrises & Fig 6, no. I \\
\hline 2007 & $483-2$ & 2 & Abrupt, deep, direct & Abrupt, deep, direct & $\begin{array}{l}\text { Semi-abrupt, deep, } \\
\text { direct }\end{array}$ & $\begin{array}{l}\text { Simple, marginal, } \\
\text { direct; inverse } \\
\text { thinned }\end{array}$ & Right bevel arris & \\
\hline 2007 & 484 & 3 & Unretouched & Unretouched & Simple, deep, direct & Simple, deep, direct & Right bevel arris & \\
\hline 2007 & $485-I$ & 2 & Simple, deep, direct & Thinned bulbar end & Small breaks & Simple, deep, inverse & None & Fig 4 , no. 5 \\
\hline 2007 & $485-2$ & I & $\begin{array}{l}\text { Simple, deep, direct; } \\
\text { ventral thinning, used? }\end{array}$ & $\begin{array}{l}\text { Semi-abrupt, deep, } \\
\text { direct }\end{array}$ & $\begin{array}{l}\text { Semi-abrupt, deep, } \\
\text { direct }\end{array}$ & $\begin{array}{l}\text { Semi-abrupt, deep, } \\
\text { direct }\end{array}$ & None & Fig 3 , no. I \\
\hline 2007 & $497-\mathrm{I}$ & 2 & Simple, marginal, direct & Thinned bulbar end & $\begin{array}{l}\text { Simple, marginal, } \\
\text { direct }\end{array}$ & $\begin{array}{l}\text { Simple, marginal, } \\
\text { direct }\end{array}$ & None & \\
\hline 2007 & 507-I & 4 & Small breaks & $\begin{array}{l}\text { Simple, marginal, } \\
\text { direct }\end{array}$ & Simple, deep, direct & Simple, deep, direct & $\begin{array}{l}\text { Right band left bevel } \\
\text { arrises }\end{array}$ & \\
\hline 2007 & $507-2$ & 4 & Unretouched & Unretouched & Simple, deep, direct & Simple, deep, direct & Right and left bevel arrises & Fig 6 , no. 2 \\
\hline 2007 & $507-3$ & 4 & Unretouched & Damaged & Simple, deep, direct & Simple, deep, direct & Right bevel arris & Fig 6 , no. 4 \\
\hline 2007 & $5 \mathrm{II}-\mathrm{I}$ & $4 \mathrm{fr}$ & Simple, marginal, direct & Simple, deep, direct & Simple, deep, direct & Half missing & Right bevel arris & Fig 7, no. 7 \\
\hline 2007 & $53 \mathrm{I}-\mathrm{I}$ & 4 & Simple, marginal, direct & Unretouched & $\begin{array}{l}\text { Semi-abrupt, deep, } \\
\text { direct }\end{array}$ & $\begin{array}{l}\text { Semi-abrupt, deep, } \\
\text { direct }\end{array}$ & Right and left bevel arrises & \\
\hline 2007 & $53 \mathrm{I}-2$ & 3 & Unretouched & $\begin{array}{l}\text { Simple, marginal, } \\
\text { direct }\end{array}$ & Simple, deep, direct & Simple, deep, direct & Right and left bevel arrises & Fig 5 , no. 4 \\
\hline 2007 & $53 I-3$ & 2 & Simple, marginal, direct & Thinned bulbar end & $\begin{array}{l}\text { Simple, marginal, } \\
\text { direct }\end{array}$ & Simple, deep, direct & Left bevel arris & \\
\hline 2007 & $53 \mathrm{I}-4$ & 3 & Simple, marginal, direct & $\begin{array}{l}\text { Simple, deep, direct, } \\
\text { notched }\end{array}$ & Bulbar end, thinned & Damaged, utilised? & Right and left bevel arrises & Fig 3 , no. 5 \\
\hline 2007 & $53 \mathrm{I}-5$ & 3 & Unretouched & $\begin{array}{l}\text { Simple, marginal, } \\
\text { direct }\end{array}$ & Damaged & $\begin{array}{l}\text { Bulbar end, thinned? } \\
\text { Damaged? }\end{array}$ & None & \\
\hline 2007 & $53 I-6$ & 4 & Small breaks & Unretouched & Simple, deep, direct & Simple, deep, direct & Right and left bevel arrises & Fig 3 , no. 4 \\
\hline 2007 & $53 \mathrm{I}-7$ & I & Direct, scaled & $\begin{array}{l}\text { Semi-abrupt, deep, } \\
\text { direct }\end{array}$ & $\begin{array}{l}\text { Semi-abrupt, deep, } \\
\text { direct }\end{array}$ & $\begin{array}{l}\text { Semi-abrupt, deep, } \\
\text { direct }\end{array}$ & None & Fig 3 , no. 2 \\
\hline 2007 & $53 \mathrm{I}-8$ & 3 & Simple, deep, inverse & Simple, deep, inverse & $\begin{array}{l}\text { Simple, deep, direct } \\
\text { and inverse }\end{array}$ & $\begin{array}{l}\text { Simple, deep, direct } \\
\text { and inverse }\end{array}$ & Right and left bevel arrises & \\
\hline 2007 & $53 I-9$ & 3 or 4 ? & Slightly damaged & Lead sheath & Lead sheath & Lead sheath & Left bevel arris & Fig 7 , no. 2 \\
\hline
\end{tabular}


Table I (cont)

\begin{tabular}{|c|c|c|c|c|c|c|c|c|}
\hline $\begin{array}{l}\text { Year of } \\
\text { excavation }\end{array}$ & $\begin{array}{l}\text { Inventory } \\
\text { no. }\end{array}$ & Class & $\begin{array}{l}\text { Leading edge } \\
\text { retouch }\end{array}$ & $\begin{array}{l}\text { Heel } \\
\text { retouch }\end{array}$ & $\begin{array}{l}\text { Right side } \\
\text { retouch }\end{array}$ & $\begin{array}{l}\text { Left side } \\
\text { retouch }\end{array}$ & $\begin{array}{l}\text { Demicone from } \\
\text { segmentation }\end{array}$ & Figure \\
\hline 2007 & 53I-IO & 3 or 4 ? & Unretouched & Lead sheath & Lead sheath & Lead sheath & Right and left bevel arrises & Fig 7, no. 4 \\
\hline 2007 & $545-\mathrm{I}$ & 2 & Simple, deep, direct & Thinned bulbar end & $\begin{array}{l}\text { Simple, marginal, } \\
\text { direct }\end{array}$ & Simple, deep, direct & None & Fig 4 , no. 4 \\
\hline 2007 & 554 & 3 or 4 ? & $\begin{array}{l}\text { Simple, marginal, } \\
\text { inverse }\end{array}$ & Lead sheath & Lead sheath & Lead sheath & None & Fig 7, no. 6 \\
\hline 2007 & $556-\mathrm{I}$ & 4 & Simple, marginal, direct & $\begin{array}{l}\text { Simple, marginal, } \\
\text { direct }\end{array}$ & Simple, deep, direct & Simple, deep, direct & Right and left bevel arrises & Fig 6, no. 6 \\
\hline 2008 & 600-I & 4 & Simple, deep, direct & Simple, deep, direct & Unretouched & Simple, deep, direct & Right bevel arris & \\
\hline 2008 & $600-2$ & 2 & Simple, marginal, direct & Thinned bulbar end & Simple, deep, direct & $\begin{array}{l}\text { Simple, marginal, } \\
\text { direct }\end{array}$ & None & \\
\hline 2008 & $600-3$ & 4 & $\begin{array}{l}\text { Inverse, thinned, } \\
\text { notched }\end{array}$ & Inverse, thinned & Simple, deep, direct & Simple, deep, direct & Right and left bevel arrises & Fig 6, no. 5 \\
\hline 2008 & 606-I & 4 & Unretouched & Unretouched & $\begin{array}{l}\text { Semi-abrupt, deep, } \\
\text { direct }\end{array}$ & $\begin{array}{l}\text { Semi-abrupt, deep, } \\
\text { direct }\end{array}$ & Right and left bevel arrises & \\
\hline 2008 & $606-2$ & 2 & Unretouched & Unretouched & $\begin{array}{l}\text { Simple, marginal, } \\
\text { direct }\end{array}$ & $\begin{array}{l}\text { Simple, marginal, } \\
\text { direct }\end{array}$ & Right bevel arris & \\
\hline 2008 & $606-3$ & 4 & Unretouched & Unretouched & $\begin{array}{l}\text { Semi-abrupt, deep, } \\
\text { direct }\end{array}$ & $\begin{array}{l}\text { Semi-abrupt, deep, } \\
\text { direct }\end{array}$ & Left bevel arris & \\
\hline 2008 & $606-4$ & 4 & $\begin{array}{l}\text { Simple, marginal, direct; } \\
\text { thinned, inverse }\end{array}$ & Simple, deep, direct & $\begin{array}{l}\text { Bulbar end; simple, } \\
\text { deep, direct }\end{array}$ & $\begin{array}{l}\text { Convex bevel; simple, } \\
\text { marginal, direct }\end{array}$ & Right and left bevel arrises & \\
\hline 2008 & $606-5$ & I & Unretouched & Simple, deep, direct & Simple, deep, direct & Simple, deep, direct & $5 \%$ cortex & \\
\hline 2008 & $607-I$ & 4 & Simple, marginal, direct & Simple, deep, direct & Simple, deep, direct & Simple, deep, direct & Right and left bevel arrises & \\
\hline 2008 & $607-2$ & $3 ?$ & Unretouched & Missing & Damaged & Simple, deep, direct & Right bevel arris & \\
\hline 2008 & $608-I$ & 4 & Unretouched & $\begin{array}{l}\text { Simple, marginal, } \\
\text { direct }\end{array}$ & Simple, deep, direct & Simple, deep, direct & Right and left bevel arrises & \\
\hline 2008 & $608-2$ & 2 & Simple, marginal, direct & $\begin{array}{l}\text { Simple, marginal, } \\
\text { direct }\end{array}$ & $\begin{array}{l}\text { Simple, marginal, } \\
\text { direct }\end{array}$ & $\begin{array}{l}\text { Simple, marginal, } \\
\text { direct }\end{array}$ & Left bevel arris & Fig 4 , no. 2 \\
\hline 2008 & 609 & 4 & Simple, marginal, direct & Unretouched & $\begin{array}{l}\text { Semi-abrupt, deep, } \\
\text { direct }\end{array}$ & $\begin{array}{l}\text { Bulbar end; simple, } \\
\text { deep, direct }\end{array}$ & Right and left bevel arrises & Fig IO, no. I \\
\hline 2008 & 6II & 3 & Simple, marginal, direct & Simple, deep, direct & Thinned bulbar end & Simple, deep, direct & None & \\
\hline 2008 & $6 \mathrm{I} 4-\mathrm{I}$ & 4 & $\begin{array}{l}\text { Simple, marginal, direct; } \\
\text { damaged }\end{array}$ & $\begin{array}{l}\text { Simple, marginal, } \\
\text { direct }\end{array}$ & $\begin{array}{l}\text { Simple, marginal, } \\
\text { direct }\end{array}$ & $\begin{array}{l}\text { Simple, marginal, } \\
\text { direct }\end{array}$ & None? & $\begin{array}{l}\text { Fig } 6, \text { no. } 5 \\
\quad \text { fig } 9, \text { no. I }\end{array}$ \\
\hline 2008 & $6 \mathrm{I} 4-2$ & I (atypical) & Simple, marginal, direct & $\begin{array}{l}\text { Simple, marginal, } \\
\text { direct }\end{array}$ & $\begin{array}{l}\text { Simple, marginal, } \\
\text { direct }\end{array}$ & $\begin{array}{l}\text { Simple, marginal, } \\
\text { direct }\end{array}$ & None & $\begin{array}{l}\text { Fig } 3 \text {, no. } 3 \\
\quad \text { fig } 9 \text {, no. } 2\end{array}$ \\
\hline 2008 & $6 I 4-3$ & 4 & Unretouched & Unretouched & $\begin{array}{l}\text { Semi-abrupt, deep, } \\
\text { direct }\end{array}$ & $\begin{array}{l}\text { Semi-abrupt, deep, } \\
\text { direct }\end{array}$ & None & Fig 9, no. 3 \\
\hline
\end{tabular}


Table I (cont)

\begin{tabular}{|c|c|c|c|c|c|c|c|c|}
\hline $\begin{array}{l}\text { Year of } \\
\text { excavation }\end{array}$ & $\begin{array}{c}\text { Inventory } \\
\text { no. }\end{array}$ & Class & $\begin{array}{l}\text { Leading edge } \\
\text { retouch }\end{array}$ & $\begin{array}{l}\text { Heel } \\
\text { retouch }\end{array}$ & $\begin{array}{l}\text { Right side } \\
\text { retouch }\end{array}$ & $\begin{array}{l}\text { Left side } \\
\text { retouch }\end{array}$ & $\begin{array}{l}\text { Demicone from } \\
\text { segmentation }\end{array}$ & Figure \\
\hline 2008 & $6 \mathrm{I} 4-\mathrm{a}$ & 4 & Unretouched & Unretouched & $\begin{array}{l}\text { Unretouched? } \\
\text { Damaged }\end{array}$ & $\begin{array}{l}\text { Simple, marginal, } \\
\text { direct? Damaged }\end{array}$ & Right bevel arris & Fig 9a \\
\hline 2008 & $6 \mathrm{I} 4-\mathrm{b}$ & 4 & Simple, marginal, direct & Unretouched & $\begin{array}{l}\text { Semi-abrupt, deep, } \\
\text { direct }\end{array}$ & $\begin{array}{l}\text { Semi-abrupt, deep, } \\
\text { direct }\end{array}$ & Right and left bevel arrises & Fig $9 b$ \\
\hline 2008 & $6 I 4-c$ & 4 & Unretouched & $\begin{array}{l}\text { Simple, marginal, } \\
\text { direct }\end{array}$ & Simple, deep, direct & Simple, deep, direct & $\begin{array}{l}\text { Left bevel arris; ventral, } \\
\text { lenticular bulbar scar }\end{array}$ & Fig 9c \\
\hline 2008 & $6 \mathrm{I} 4-\mathrm{d}$ & 4 & Simple, marginal, direct & $\begin{array}{l}\text { Simple, marginal, } \\
\text { direct, ventral } \\
\text { thinning }\end{array}$ & $\begin{array}{l}\text { Simple, deep, direct, } \\
\text { ventral thinning }\end{array}$ & Missing & None & Fig 9d \\
\hline 2008 & $614-e$ & 4 & Unretouched & Unretouched & Simple, deep, direct & Missing & Right bevel arris & Fig 9e \\
\hline 2008 & $6 I 4-f$ & 4 & Simple, marginal, direct & Simple, deep, direct & Simple, deep, direct & Simple, deep, direct & Right and left bevel arrises & Fig of \\
\hline 2008 & $62 \mathrm{I}-\mathrm{I}$ & 3 & Simple, marginal, direct & Simple, deep, direct & $\begin{array}{l}\text { Simple, marginal, } \\
\text { direct }\end{array}$ & $\begin{array}{l}\text { Simple, marginal, } \\
\text { direct }\end{array}$ & None & \\
\hline 2008 & 622 & 4 & Small breaks & Damaged & $\begin{array}{l}\text { Semi-abrupt, deep, } \\
\text { direct }\end{array}$ & $\begin{array}{l}\text { Semi-abrupt, deep, } \\
\text { direct }\end{array}$ & Left bevel arris & \\
\hline 2008 & $624-I$ & 4 & Utilised (heavily) & Simple, deep, direct & $\begin{array}{l}\text { Bulbar end; semi- } \\
\text { abrupt, deep, } \\
\text { direct }\end{array}$ & $\begin{array}{l}\text { Semi-abrupt, deep, } \\
\text { direct }\end{array}$ & Right and left bevel arrises & Fig Io, no. 4 \\
\hline 2008 & $624-2$ & 4 & Missing & Simple, deep, inverse & Bulbar end & $\begin{array}{l}\text { Semi-abrupt, deep, } \\
\text { direct, convex }\end{array}$ & Right bevel arris & \\
\hline 2008 & 625 & 4 & Unretouched & Unretouched & Simple, deep, direct & Simple, deep, direct & Right and left bevel arrises & \\
\hline 2008 & $65 \mathrm{I}$ & 3 & Unretouched & Unretouched & Simple, deep, direct & Simple, deep, direct & Left bevel arris & \\
\hline 2008 & $653-3$ & 3 & Utilises, notched & Utilised, notched & Thinned bulbar end & $\begin{array}{l}\text { Semi-abrupt, deep, } \\
\text { direct, slightly } \\
\text { convex }\end{array}$ & Left bevel arris & Fig 5, no. 5 \\
\hline 2008 & 660-I & 3 & Inverse, thinned & Unretouched & Simple, deep, direct & Simple, deep, direct & Right and left bevel arrises & Fig 5, no. 2 \\
\hline 2008 & $660-2$ & 2 & Simple, marginal, direct & Thinned bulbar end & Simple, deep, direct & $\begin{array}{l}\text { Simple, marginal, } \\
\text { direct }\end{array}$ & $\begin{array}{l}\text { Ventral, lenticular bulbar } \\
\text { scar }\end{array}$ & Fig 5, no. I \\
\hline 2008 & $660-3$ & 4 & $\begin{array}{l}\text { Simple, marginal, } \\
\text { inverse }\end{array}$ & $\begin{array}{l}\text { Simple, marginal, } \\
\text { direct }\end{array}$ & $\begin{array}{l}\text { Simple, marginal, } \\
\text { direct; and inverse }\end{array}$ & $\begin{array}{l}\text { Simple, marginal, } \\
\text { direct and inverse }\end{array}$ & Left bevel arris & \\
\hline 2008 & $660-4$ & 4 & Unretouched & $\begin{array}{l}\text { Simple, marginal, } \\
\text { direct }\end{array}$ & Simple, deep, direct & Simple, deep, direct & Right and left bevel arrises & \\
\hline 2008 & $663-I$ & 4 (atypical) & Unretouched & $\begin{array}{l}\text { Simple, marginal, } \\
\text { inverse }\end{array}$ & Simple, deep, direct & Simple, deep, direct & Right and left bevel arrises & $\begin{array}{l}\text { Fig } 6, \text { no. } 7 \\
\quad \text { fig Io, no. } 2\end{array}$ \\
\hline 2008 & $669-\mathrm{I}$ & 3 & $\begin{array}{l}\text { Simple, marginal, direct, } \\
\text { partial }\end{array}$ & Unretouched & $\begin{array}{l}\text { Semi-abrupt, deep, } \\
\text { direct }\end{array}$ & $\begin{array}{l}\text { Semi-abrupt, deep, } \\
\text { direct }\end{array}$ & Right bevel arris & Fig 5, no. 3 \\
\hline 2008 & $669-2$ & 4 & Simple, marginal, direct & $\begin{array}{l}\text { Simple, marginal, } \\
\text { direct }\end{array}$ & Simple, deep, direct & Simple, deep, direct & None & Fig 6, no. 3 \\
\hline 2008 & $673-\mathrm{I}$ & 4 & Simple, marginal, direct & $\begin{array}{l}\text { Simple, marginal, } \\
\text { direct }\end{array}$ & Simple, deep, direct & Thinned bulbar end & None & \\
\hline
\end{tabular}


Table I (cont)

\begin{tabular}{|c|c|c|c|c|c|c|c|c|}
\hline $\begin{array}{l}\text { Year of } \\
\text { excavation }\end{array}$ & $\begin{array}{c}\text { Inventory } \\
\text { no. }\end{array}$ & Class & $\begin{array}{l}\text { Leading edge } \\
\text { retouch }\end{array}$ & $\begin{array}{l}\text { Heel } \\
\text { retouch }\end{array}$ & $\begin{array}{l}\text { Right side } \\
\text { retouch }\end{array}$ & $\begin{array}{l}\text { Left side } \\
\text { retouch }\end{array}$ & $\begin{array}{l}\text { Demicone from } \\
\text { segmentation }\end{array}$ & Figure \\
\hline 2008 & $673-2$ & 4 & Unretouched & $\begin{array}{l}\text { Simple, marginal, } \\
\text { inverse }\end{array}$ & Flat, invasive, direct & Flat, invasive, direct & Right and left bevel arrises & \\
\hline 2008 & $673-3$ & 2 & Simple, marginal, direct & Simple, deep, direct & $\begin{array}{l}\text { Simple, marginal, } \\
\text { inverse }\end{array}$ & $\begin{array}{l}\text { Simple, marginal, } \\
\text { direct }\end{array}$ & Left bevel arris & Fig 4 , no. I \\
\hline 2008 & 674-10 & 3 & Unretouched & $\begin{array}{l}\text { Simple, deep, direct, } \\
\text { partial }\end{array}$ & Simple, deep, direct & Simple, deep, direct & Left bevel arris & \\
\hline 2008 & 675 & 4 & Unretouched & $\begin{array}{l}\text { Simple, marginal, } \\
\text { direct }\end{array}$ & Simple, deep, direct & Simple, deep, direct & Right bevel arris & \\
\hline 2009 & $68 I$ & 4 & $\begin{array}{l}\text { Simple, deep, inverse, } \\
\text { partial }\end{array}$ & Small breaks & $\begin{array}{l}\text { Simple, marginal, } \\
\text { direct }\end{array}$ & $\begin{array}{l}\text { Bulbar end; semi- } \\
\text { abrupt, deep, direct }\end{array}$ & $\begin{array}{l}\text { Right bevel arris; ventral, } \\
\text { lenticular bulbar scar }\end{array}$ & Fig Io, no. 3 \\
\hline 2009 & 690 & 4 & Unretouched & Simple, deep, direct & Simple, deep, direct & Simple, deep, direct & Right bevel arris & \\
\hline 2009 & $694-\mathrm{I}$ & 3 & Unretouched & $\begin{array}{l}\text { Simple, marginal, } \\
\text { inverse } \\
\text { (use damage?) }\end{array}$ & Simple, deep, direct & Simple, deep, direct & Right bevel arris & \\
\hline 2009 & 696 & 4 & Unretouched & Simple, deep, direct & $\begin{array}{l}\text { Simple, marginal, } \\
\text { inverse }\end{array}$ & $\begin{array}{l}\text { Bulbar end; simple, } \\
\text { deep, direct }\end{array}$ & $\begin{array}{l}\text { Right bevel arris; ventral, } \\
\text { lenticular bulbar scar }\end{array}$ & \\
\hline 2009 & 700 & 2 & Simple, marginal, direct & $\begin{array}{l}\text { Simple, deep, direct; } \\
\text { thinned bulbar end }\end{array}$ & $\begin{array}{l}\text { Simple, marginal, } \\
\text { direct }\end{array}$ & $\begin{array}{l}\text { Simple, marginal, } \\
\text { direct }\end{array}$ & None & \\
\hline 2009 & $718-1$ & 4 & Simple, marginal, direct & $\begin{array}{l}\text { Semi-abrupt, marginal, } \\
\text { direct }\end{array}$ & Simple, deep, direct & Simple, deep, direct & Left bevel arris & \\
\hline 2009 & 722 & 4 & Small breaks & Simple, deep, direct & Simple, deep, direct & Simple, deep, direct & Right bevel arris & \\
\hline 2009 & 723 & 4 & Small breaks & Unretouched & Simple, deep, direct & Missing & Right bevel arris & \\
\hline 2009 & $727-\mathrm{I}$ & 4 & Inverse, thinned & Simple, deep, direct & Simple, deep, direct & Simple, deep, direct & Right and left bevel arrises & \\
\hline 2009 & 750 & 3 & Unretouched & $\begin{array}{l}\text { Simple, marginal, } \\
\text { direct }\end{array}$ & $\begin{array}{l}\text { Semi-abrupt, deep, } \\
\text { direct }\end{array}$ & $\begin{array}{l}\text { Semi-abrupt, deep, } \\
\text { direct }\end{array}$ & None & \\
\hline 2009 & 752 & 2 & Simple, marginal, direct & $\begin{array}{l}\text { Simple, marginal, } \\
\text { direct }\end{array}$ & Small breaks & Small breaks & None & \\
\hline 2009 & $758-\mathrm{I}$ & 4 & Simple, marginal, direct & $\begin{array}{l}\text { Simple, marginal, } \\
\text { direct }\end{array}$ & Simple, deep, direct & Simple, deep, direct & Right and left bevel arris & \\
\hline 2010 & 798 & 4 & Simple, marginal, direct & $\begin{array}{l}\text { Simple, marginal, } \\
\text { direct }\end{array}$ & Simple, deep, direct & Simple, deep, direct & None & \\
\hline 2010 & $804-I$ & 3 & $\begin{array}{l}\text { Simple, marginal, direct, } \\
\text { partial }\end{array}$ & Unretouched & Simple, deep, direct & Simple, deep, direct & Right and left bevel arris & \\
\hline $201 \mathrm{II}$ & 839 & 4 & Unretouched & Unretouched & Simple, deep, direct & Simple, deep, direct & Right and left bevel arris & Fig 7 , no. I \\
\hline
\end{tabular}


Table 2. Provenance, material, manufacture and raw material characteristics of the Mercurio gunflints

\begin{tabular}{|c|c|c|c|c|c|c|c|c|c|c|c|c|c|c|c|}
\hline 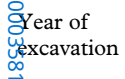 & $\begin{array}{l}\text { Inventory } \\
\text { no. }\end{array}$ & Square & Measures (mm) & Condition & Part & Blank & Material & Colour & $\begin{array}{l}\text { Munsell } \\
\text { code }\end{array}$ & Shape & $\begin{array}{l}\text { Percussion } \\
\text { bulb }\end{array}$ & Arrises & $\begin{array}{l}\text { Use wear } \\
\text { traces }\end{array}$ & Notes & Figure \\
\hline 㲾2006 & $328-\mathrm{I}$ & 8 & $33 \times 25 \times 9$ & $\begin{array}{l}\text { Broken prox. } \\
\text { end right corner }\end{array}$ & Proximal & Blade & Flint & Black & $\mathrm{N} \mathrm{2.5/}$ & Rectangular & Yes & I central & No & Patinated, incrustations & \\
\hline 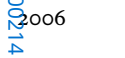 & $328-2$ & 8 & $31 \times 27 \times 5$ & Complete & Proximal & Blade & Flint & $\begin{array}{l}\text { Dark bluish } \\
\text { grey }\end{array}$ & $5 \mathrm{~B} 4 / \mathrm{I}$ & Rectangular & Yes, thinned & I transversal & No & Incrustations (metal?) & Fig 4 , no. 3 \\
\hline 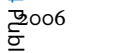 & 350 & 8 & $35 \times 27 \times 6$ & $\begin{array}{l}\text { Broken prox. } \\
\text { end right corner }\end{array}$ & Medial? & Blade & Flint & Black & $\mathrm{N} \mathrm{2.5/}$ & Rectangular & No & 2 parallel & No & Lighter grey spots & \\
\hline 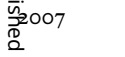 & $4 \mathrm{I} 7-\mathrm{I}$ & 8 & $36 x$ ? $x$ ? & Complete & Medial & Blade? & Flint & Whitish patina & Unknown & Rectangular & No & I central & No & $\begin{array}{l}\text { White patina }(\mathrm{N} 8 /) \text {, } \\
\text { lead sheath cover }\end{array}$ & Fig 7, no. 3 \\
\hline $\bar{g}_{2} 007$ & 423 & 8 & $25 \times 22 \times 5$ & Complete & Medial & Blade & Flint & Black & $\mathrm{N} 2.5 /$ & Rectangular & No & 2 irregular & No & None & Fig 4 , no. 6 \\
\hline 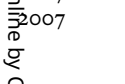 & 474 & 8 & $28 \times 25 \times 6$ & Complete & Medial & Blade & Flint & Brown & IOYR $5 / 3$ & Rectangular & No & I asymmetric & No & $\begin{array}{l}\text { Lessinian flint (Scaglia } \\
\text { Variegata); inserted } \\
\text { in the cock of a pistol? }\end{array}$ & Fig 6, no. I \\
\hline 2007 & $483-2$ & 8 & $28 \times 26 \times 7$ & Complete & Medial & Blade & Flint & Very dark grey & $\mathrm{N}_{3} /$ & Rectangular & $M$ & I transversal & No & None & \\
\hline $\mathfrak{Z}_{2007}^{2}$ & 484 & 8 & $29 \times 26 \times 6$ & Complete & Medial & Blade & Flint & Very dark grey & $\mathrm{N}_{3}$ & Rectangular & No & 2 irregular & No & Slightly variegated flint & \\
\hline ב्र & 485 -I & 8 & $33.5 \times 26.5 \times 8$ & Complete & Proximal & Blade & Flint & Very dark grey & $\mathrm{N}_{3} /$ & Rectangular & Yes, thinned & I asymmetric & No & None & Fig 4 , no. 5 \\
\hline 帯 & $485-2$ & 8 & $23 \times 21 \times 6$ & Complete & Medial? & Flake? & Flint & Unknown & Unknown & D-shaped & No & None & Yes & Burnt & Fig 3 , no. I \\
\hline S.007 & $497-\mathrm{I}$ & 8 & $37 \times 32 \times 8.5$ & Complete & Proximal & Blade & Flint & Very dark grey & $\mathrm{N}_{3} /$ & Rectangular & Yes & 2 convergent & No & $\begin{array}{l}\text { Ventral, lenticular bulb } \\
\text { scar }\end{array}$ & \\
\hline$\frac{0}{w^{2}} 007$ & $507-\mathrm{I}$ & 8 & $24 \times 21.5 \times 4$ & Complete & Medial & Blade & Flint & Black & $\mathrm{N} 2.5 /$ & Rectangular & No & I parallel & No & None & \\
\hline ₹2007 & $507-2$ & 8 & $29 \times 24.5 \times 4$ & Complete & Medial & Blade & Flint & Very dark grey & $\mathrm{N}_{3} /$ & Rectangular & No & I parallel & No & None & Fig 6, no. 2 \\
\hline 蛋007 & $507-3$ & 8 & $34 \times 25 \times 8$ & $\begin{array}{l}\text { Right lateral } \\
\text { detachment }\end{array}$ & Medial & Blade & Flint & Very dark grey & $\mathrm{N}_{3} /$ & Rectangular & No & I irregular & No & None & Fig 6 , no. 4 \\
\hline 2007 & 5II-I & 8 & $(23) \times 23 \times 5.5$ & $\begin{array}{l}\text { Fragment, half } \\
\text { missing }\end{array}$ & Medial & Blade & Flint & $\begin{array}{l}\text { Dark greenish } \\
\text { grey }\end{array}$ & $5 \mathrm{GY}_{4 / \mathrm{I}}$ & Rectangular & No & I asymmetric & No & $\begin{array}{l}\text { Concreted with two } \\
\text { pistols }\end{array}$ & Fig 7 , no. 7 \\
\hline 2007 & $53 \mathrm{I}-\mathrm{I}$ & 8 & $28 \times 24 \times 7$ & Complete & Medial & Blade & Flint & Black & $\mathrm{N} \mathrm{2.5/}$ & Rectangular & No & I parallel & No & None & \\
\hline 2007 & $53 \mathrm{I}-2$ & 8 & $35 \times 31 \times 9$ & Complete & Medial & Blade & Flint & Grey & $\mathrm{N}_{5} /$ & Rectangular & No & 2 irregular & No & None & Fig 5 , no. 4 \\
\hline 2007 & $53 \mathrm{I}-3$ & 8 & $33 \times 28 \times 7$ & Complete & Proximal & Blade & Flint & Grey & $\mathrm{N}_{5} /$ & Rectangular & Yes, thinned & I irregular & No & None & \\
\hline 2007 & $53 \mathrm{I}-4$ & 8 & $34 \times 28 \times 7$ & $\begin{array}{l}\text { Broken prox. end } \\
\text { right corner }\end{array}$ & Proximal & Blade & Flint & Dark grey & $\mathrm{N}_{4} /$ & Rectangular & Yes, thinned & 2 irregular & Yes & Lighter grey spots & Fig $_{3}$, no. 5 \\
\hline 2007 & $53 \mathrm{I}-5$ & 8 & $34 \times 26.5 \times 7$ & $\begin{array}{l}\text { Broken prox.-dist. } \\
\text { right corners }\end{array}$ & Proximal & Blade & Flint & Dark grey & $\mathrm{N}_{4} /$ & Rectangular & Yes, thinned? & I irregular & No & $5 \%$ cortex & \\
\hline 2007 & $53 \mathrm{I}-6$ & 8 & $33 \times 29 \times 8.5$ & Complete & Medial & Blade & Flint & $\begin{array}{l}\text { Dark greenish } \\
\text { grey }\end{array}$ & $5 \mathrm{GY} 4 / \mathrm{I}$ & Trapezoidal & No & I central & No & None & Fig 3 , no. 4 \\
\hline 2007 & $53 \mathrm{I}-7$ & 8 & $27 \times 28.5 \times 5$ & Complete & Medial & Flake & Flint & White patina & Unknown & D-shaped & No & I irregular & No & $\begin{array}{l}\text { White patina }(\mathrm{N} 8 /) \text {, } \\
\text { translucent }\end{array}$ & Fig 3 , no. 2 \\
\hline 2007 & $53 \mathrm{I}-8$ & 8 & $30.5 \times 26 \times 8$ & Complete & Medial & Flake? & Flint & Grey & $\mathrm{N}_{5} /$ & $\begin{array}{l}\text { Trapezoidal } \\
\text { (oval- } \\
\text { shaped) }\end{array}$ & No & 2 irregular & No & $\begin{array}{l}\text { Reddish brown spots } \\
\quad\left(5 \mathrm{YR}_{5} / 4\right)\end{array}$ & \\
\hline 2007 & $53 \mathrm{I}-9$ & 8 & $29 \times$ ? $x ?$ & Complete & Medial? & Blade? & Flint & Whitish patina & Unknown & Rectangular & No & Unknown & Yes & $\begin{array}{l}\text { White patina }(\mathrm{N} 8 /) \text {, } \\
\text { lead sheath cover, } \\
\text { incrustations }\end{array}$ & Fig 7 , no. 2 \\
\hline 2007 & 53I-IO & 8 & $30 x$ ? ? & Complete & Medial? & Blade & Flint & Very dark grey & $\mathrm{N}_{3} /$ & Rectangular & No & & No & Lead sheet cover & Fig 7 , no. 4 \\
\hline 2007 & $545-\mathrm{I}$ & 8 & $29.5 \times 24 \times 5.5$ & Complete & Proximal & Blade & Flint & Black & $\mathrm{N} 2.5 /$ & Rectangular & Yes, thinned & 2 parallel & No & None & Fig 4 , no. 4 \\
\hline
\end{tabular}


Table 2 (cont)

\begin{tabular}{|c|c|c|c|c|c|c|c|c|c|c|c|c|c|c|c|}
\hline 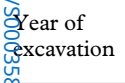 & $\begin{array}{c}\text { Inventory } \\
\text { no. }\end{array}$ & Square & Measures (mm) & Condition & Part & Blank & Material & Colour & $\begin{array}{l}\text { Munsell } \\
\text { code }\end{array}$ & Shape & $\begin{array}{l}\text { Percussion } \\
\text { bulb }\end{array}$ & Arrises & $\begin{array}{l}\text { Use wear } \\
\text { traces }\end{array}$ & Notes & Figure \\
\hline $\begin{array}{l}\sqrt{2007} \\
\frac{2}{8}\end{array}$ & 554 & 8 & $28 x ? \times ?$ & Complete & Medial & Blade & Flint & Whitish patina & Unknown & Rectangular & No & I central? & No & $\begin{array}{l}\text { White patina }(\mathrm{N} 8 /) \text {, } \\
\text { lead sheath cover, } \\
\text { incrustations }\end{array}$ & Fig 7, no. 6 \\
\hline 2007 & 556-I & 8 & $28 \times 25 \times 6$ & Complete & Medial & Blade & Flint & Very dark grey & $\mathrm{N}_{3} /$ & Rectangular & No & I central & No & None & Fig 6 , no. 6 \\
\hline 2008 & $600-1$ & 9 & $38 \times 33 \times 9$ & Complete & Proximal & Flake? & Flint & Black & $\mathrm{N}_{2.5} /$ & Rectangular & Yes & I irregular & No & None & \\
\hline$\frac{\sigma^{2}}{\overline{5}}$ & $600-2$ & 9 & $32.5 \times 32 \times 9$ & Complete & Proximal & Blade & Flint & $\begin{array}{l}\text { Dark greenish } \\
\text { grey }\end{array}$ & $5 \mathrm{GY} 4 / \mathrm{I}$ & Squared & Yes, thinned & 2 convergent & No & Striped grey & \\
\hline 罂 & $600-3$ & 9 & $32 \times 22.5 \times 6$ & Complete & Medial & Blade & Flint & $\begin{array}{l}\text { Dark greenish } \\
\text { grey }\end{array}$ & $5 \mathrm{GY} 4 / \mathrm{I}$ & $\begin{array}{l}\text { Rectangular, } \\
\text { elongated }\end{array}$ & No & I central & Yes & Lighter grey spots & \\
\hline 层,008 & 606-I & 9 & $36 \times 25 \times 6$ & Complete & Medial & Blade & Flint & $\begin{array}{l}\text { Dark greenish } \\
\text { grey }\end{array}$ & $5 \mathrm{GY}_{4} / \mathrm{I}$ & Rectangular & No & I central & No & Striped grey & \\
\hline एृ2008 & $606-2$ & 9 & $32 \times 28 \times 4.5$ & Complete & Medial & Blade & Flint & Grey & $\mathrm{N}_{5} /$ & Rectangular & No & 2 transversal & No & Lighter grey spots & \\
\hline 吾 & $606-3$ & 9 & $35 \times 32 \times 10$ & Complete & Medial & Flake & Flint & $\begin{array}{l}\text { Dark greenish } \\
\text { grey }\end{array}$ & $5 \mathrm{GY}_{4} / \mathrm{I}$ & Rectangular & No & 2 irregular & No & Small lighter spots & \\
\hline 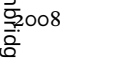 & $606-4$ & 9 & $30 \times 25 \times 8$ & Complete & Proximal & Blade & Flint & Greenish grey & N 6/ & $\begin{array}{l}\text { Rectangular } \\
\text { (trapezoidal) }\end{array}$ & Yes, thinned? & I central & No & None & \\
\hline 冚 & $606-5$ & 9 & $30.5 \times 26 \times 4$ & Complete & Medial & Blade? & Flint & Greenish grey & N 6/ & $\begin{array}{l}\text { Trapezoidal, } \\
\text { convex ends }\end{array}$ & No & I central & No & Lighter grey spots & \\
\hline 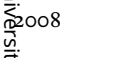 & 607-I & 9 & $32 \times 24 \times 7$ & $\begin{array}{l}\text { Left upper } \\
\text { corner missing }\end{array}$ & Medial & Blade & Flint & Very dark grey & $\mathrm{N}_{3} /$ & Rectangular & No & 2 irregular & No & Lighter grey spots & \\
\hline$\sum_{2}^{2} 008$ & $607-2$ & 9 & $30.5 \times 22 \times 6.5$ & $\begin{array}{l}\text { Left side partly } \\
\text { missing }\end{array}$ & Medial & Blade & Flint & Black & $\mathrm{N}_{2.5 /}$ & Rectangular & Yes, thinned & 2 irregular & No & None & \\
\hline 幽oo8 & $608-1$ & 9 & $25 \times 23 \times 5.5$ & Complete & Medial & Blade & Flint & Very dark grey & $\mathrm{N}_{3} /$ & Rectangular & No & I irregular & No & None & \\
\hline 2008 & $608-2$ & 9 & $28.5 \times 26 \times 4$ & Complete & Medial & Blade & Flint & Very dark grey & $\mathrm{N}_{3} /$ & Rectangular & No & None & No & Lighter grey spots & $\operatorname{Fig}_{4}$, no. 2 \\
\hline 2008 & 609 & 9 & $36 \times 27 \times 9$ & Complete & Proximal & Blade & Flint & Black & $\mathrm{N} 2.5 /$ & Rectangular & Yes & I oblique & No & None & Fig Io, no. I \\
\hline 2008 & 6II & 9 & $35.5 \times 30 \times 5.5$ & Complete & Proximal & Blade & Flint & Black & $\mathrm{N} 2.5 /$ & Rectangular & Yes, thinned & I central & No & None, incrustations & \\
\hline 2008 & 6I4-I & 9 & $34 \times 27 \times 5$ & $\begin{array}{l}\text { Complete } \\
\quad \text { (from a flake) }\end{array}$ & Medial & Flake & Flint & Dark grey & $\mathrm{N}_{4} /$ & Rectangular & No & I oblique & No & $\begin{array}{l}\text { Concreted with a } \\
\text { cannon gunlock, } \\
\text { metal residues }\end{array}$ & $\begin{array}{l}\text { Fig } 7 \text {, no. 5; } \\
\quad \text { fig } 9 \text {, no. I }\end{array}$ \\
\hline 2008 & $6 \mathrm{I} 4-2$ & 9 & $30 \times 26.5 \times 4$ & Complete & Medial & Blade & Flint & Black & $\mathrm{N}_{2.5} /$ & D-shaped & No & I oblique & No & $\begin{array}{l}\text { Concreted with a } \\
\text { cannon gunlock, } \\
\text { metal residues }\end{array}$ & $\begin{array}{l}\text { Fig } 3 \text {, no. } 3 ; \\
\quad \text { fig } 9 \text {, no. } 2\end{array}$ \\
\hline 2008 & $6 \mathrm{I} 4-3$ & 9 & $31.5 \times 28 \times 6$ & Complete & Medial & Blade & Flint & Black & $\mathrm{N} 2.5 /$ & Rectangular & No & I oblique & No & $\begin{array}{l}\text { Concreted with a } \\
\text { cannon gunlock, } \\
\text { metal residues }\end{array}$ & Fig 9, no. 3 \\
\hline 2008 & $614-a$ & 9 & $(29) \times(23.5) \times 4$ & $\begin{array}{l}\text { Three corners } \\
\text { missing }\end{array}$ & Medial & Flake? & Flint & Black & $\mathrm{N} 2.5 /$ & Rectangular & No & I irregular? & No & $\begin{array}{l}\text { Concreted with a } \\
\text { cannon gunlock, } \\
\text { metal residues }\end{array}$ & Fig 9a \\
\hline 2008 & $6 \mathrm{I} 4-\mathrm{b}$ & 9 & $28 \times 19 \times 5.5$ & Complete & Medial & Blade & Flint & Dark grey & $\mathrm{N}_{4} /$ & Rectangular & No & I central & No & $\begin{array}{l}\text { Concreted with a } \\
\text { cannon gunlock, } \\
\text { metal residues }\end{array}$ & Fig $9 b$ \\
\hline 2008 & $614-c$ & 9 & $27 \times 27 \times 5.5$ & $\begin{array}{l}\text { Complete ( } 3 \text { pieces } \\
\text { conjoined) }\end{array}$ & Medial & Flake & Flint & Dark grey & $\mathrm{N}_{4} /$ & Squared & Ventral scar & I lateral & No & $\begin{array}{l}\text { Concreted with a } \\
\text { cannon gunlock, } \\
\text { metal residues, three } \\
\text { conjoined pieces }\end{array}$ & Fig $9 \mathrm{c}$ \\
\hline
\end{tabular}


Table 2 (cont)

\begin{tabular}{|c|c|c|c|c|c|c|c|c|c|c|c|c|c|c|c|}
\hline $\begin{array}{l}\text { Whear of } \\
\text { Excavation } \\
\text { Ex } \\
\text { Wu }\end{array}$ & $\begin{array}{c}\text { Inventory } \\
\text { no. }\end{array}$ & Square & Measures (mm) & Condition & Part & Blank & Material & Colour & $\begin{array}{l}\text { Munsell } \\
\text { code }\end{array}$ & Shape & $\begin{array}{l}\text { Percussion } \\
\text { bulb }\end{array}$ & Arrises & $\begin{array}{l}\text { Use wear } \\
\text { traces }\end{array}$ & Notes & Figure \\
\hline $\begin{array}{l}\text { 2008 } \\
\text { ज̃ } \\
\vec{\circ} \\
\text { Oे } \\
\text { ज़ } \\
\vec{A}\end{array}$ & $6 \mathrm{I}_{4}-\mathrm{d}$ & 9 & $(21.5) \times 27 \times 6$ & $\begin{array}{l}\text { Fragment } \\
\text { (right half) }\end{array}$ & Medial? & Flake? & Flint & Dark grey & $\mathrm{N}_{4} /$ & Rectangular & Thinned & 2 irregular & Yes? & $\begin{array}{l}\text { Concreted with a cannon } \\
\text { gunlock, metal } \\
\text { residues, patinated, } \\
\text { light yellowish brown } \\
\text { spots }(2.5 \mathrm{Y} 6 / 3)\end{array}$ & Fig 9d \\
\hline $\begin{array}{l}\frac{b}{20008} \\
\frac{\bar{c}}{\overline{\bar{n}}} \\
\frac{\sqrt{2}}{2}\end{array}$ & $614-e$ & 9 & $25.5 \times 19.5 \times 5.5$ & Distal edge missing & Medial & Blade & Flint & Dark grey & $\mathrm{N}_{4} /$ & Rectangular & No & I central & No & $\begin{array}{l}\text { Concreted with a } \\
\text { cannon gunlock, } \\
\text { metal residues }\end{array}$ & Fig 9e \\
\hline 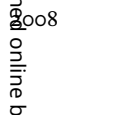 & $6 \mathrm{I} 4-\mathrm{f}$ & 9 & $30.5 \times 25 \times 5.5$ & $\begin{array}{l}\text { Left upper } \\
\quad \text { corner missing }\end{array}$ & Medial & Blade & Flint & Dark grey & $\mathrm{N}_{4} /$ & Rectangular & Yes, thinned & I oblique & No & $\begin{array}{l}\text { Concreted with a } \\
\text { cannon gunlock, } \\
\text { metal residues, } \\
\text { patinated }\end{array}$ & Fig of \\
\hline ర్to08 & $62 \mathrm{I}-\mathrm{I}$ & 9 & $34 \times 29.5 \times 6$ & Complete & Medial & Flake? & Flint & Black & $\mathrm{N}_{2.5} /$ & Rectangular & No & 2 oblique & No & None & \\
\hline Q008 & 622 & 9 & $25 \times 22.5 \times 4.5$ & Complete & Medial & Blade & Flint & Black & $\mathrm{N} 2.5 /$ & Rectangular & No & I oblique & No & None & \\
\hline 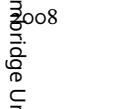 & $624-\mathrm{I}$ & 9 & $4 \mathrm{I} \times 34 \times 10$ & $\begin{array}{l}\text { Complete, left side } \\
\text { reshaped }\end{array}$ & Proximal & Flake & Flint & Grey & $\mathrm{N}_{5 /}$ & $\begin{array}{l}\text { Rectangular } \\
\text { (butterfly) }\end{array}$ & Yes & I transversal & Yes & $\begin{array}{l}\text { Butterfly-shaped, } \\
\text { reused as a fire flint? } \\
\text { Small light brown } \\
\text { spots }\end{array}$ & Fig Io, no. 4 \\
\hline 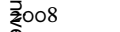 & $624-2$ & 9 & $30 \times 24 \times(8)$ & Left side missing & Proximal & Flake? & Flint & Unknown & Unknown & Rectangular & Yes & 2 convergent & No & Burnt, metal residue & \\
\hline 商o08 & 625 & 9 & $31.5 \times 27.5 \times 6$ & Complete & Medial & Blade & Flint & Grey & $\mathrm{N}_{5} /$ & Rectangular & No & I central & No & None & \\
\hline$\frac{n}{2008}$ & $65 \mathrm{I}$ & 9 & $30 \times 27.5 \times 5.5$ & Complete & Medial & Blade & Flint & Grey (burnt?) & $\mathrm{N}_{5} /$ & Rectangular & No & 2 parallel & No & Burnt?, concretions & \\
\hline జ్ర008 & $653-3$ & 9 & $30 \times 24 \times 5.5$ & $\begin{array}{l}\text { Complete, sides } \\
\text { reshaped }\end{array}$ & Proximal & Blade & Flint & Dark grey & $\mathrm{N}_{4}^{\prime}$ & $\begin{array}{l}\text { Rectangular } \\
\text { (butterfly) }\end{array}$ & Yes, thinned & 2 central & Yes & $\begin{array}{l}\text { Butterfly-shaped, } \\
\text { reused as a fire flint? }\end{array}$ & Fig 5, no. 5 \\
\hline$\tilde{2}_{2008}$ & 660-I & 9 & $27.5 \times 25.5 \times 6.5$ & Complete & Medial & Blade & Flint & Dark grey & $\mathrm{N}_{4} /$ & Rectangular & No & 2 central & No & None & Fig 5 , no. 2 \\
\hline 2008 & $660-2$ & 9 & $28 \times 25 \times 5$ & Complete & Proximal & Blade & Flint & Black & $\mathrm{N} 2.5 /$ & Rectangular & Yes, thinned & I transversal & No & $\begin{array}{l}\text { Ventral, lenticular } \\
\text { bulbar scar, metal } \\
\text { residue }\end{array}$ & Fig 5, no. I \\
\hline 2008 & $660-3$ & 9 & $37.5 \times 32.5 \times 6$ & Complete & Proximal & Blade & Flint & Black & $\mathrm{N} 2.5 /$ & Rectangular & Yes, thinned & I central & No & None & \\
\hline 2008 & $660-4$ & 9 & $28 \times 22 \times 5.5$ & Complete & Medial & Blade & Flint & Dark grey & $\mathrm{N}_{4}^{\prime}$ & Rectangular & No & I central & No & Metal residues & \\
\hline 2008 & 663-I & 9 & $34 \times 23.5 \times 3.5$ & Complete & Proximal & Blade & Flint & Bluish grey & $5 \mathrm{~B} 5 / \mathrm{I}$ & Rectangular & Yes, thinned & I lateral & No & Lighter grey spots & $\begin{array}{l}\text { Fig 6, no. } 7 \text {; } \\
\text { fig Io, no. } 2\end{array}$ \\
\hline 2008 & 669-I & 9 & $36 \times 28 \times 5$ & Complete & Medial & Blade & Flint & Dark grey & $\mathrm{N}_{4} /$ & $\begin{array}{l}\text { Rectangular } \\
\text { (trapezoidal) }\end{array}$ & No & 2 oblique & No & Lighter grey stripes & Fig 5, no. 3 \\
\hline 2008 & $669-2$ & 9 & $33 \times 27 \times 4$ & Complete & Medial & Blade & Flint & Bluish grey & $5 \mathrm{~B} 6 / \mathrm{I}$ & Rectangular & No & I oblique & No & Lighter grey stripes & Fig 6, no. 3 \\
\hline 2008 & 673-I & 9 & $33 \times 27 \times 6$ & Complete & Proximal & Blade & Flint & Dark grey & $\mathrm{N}_{4} /$ & Rectangular & Yes, thinned & Irregular & No & None & \\
\hline 2008 & $673-2$ & 9 & $28.5 \times 22 \times 6$ & Complete & Medial & Blade & Flint & Grey & $\mathrm{N}_{5} /$ & Rectangular & No & I central & Yes & None, patinated & \\
\hline 2008 & $673-3$ & 9 & $26.5 \times 24.5 \times 5$ & Complete & Medial & Blade & Flint & Grey & $\mathrm{N}_{5} /$ & Rectangular & No & 2 parallel & No & None & Fig 4 , no. I \\
\hline 2008 & 674-10 & 9 & $35 \times 29 \times 6$ & Complete & Medial & Blade & Flint & Black & $\mathrm{N} \mathrm{2.5/}$ & Rectangular & No & 2 parallel & No & None & \\
\hline 2008 & 675 & 9 & $32 \times 23 \times 5$ & Complete & Medial & Blade & Flint & Black & $\mathrm{N} 2.5 /$ & Rectangular & No & I oblique & No & None & \\
\hline 2009 & $68 \mathrm{I}$ & 9 & $31.5 \times 28 \times 8$ & Complete & Proximal & Flake & Flint & Black & $\mathrm{N} 2.5 /$ & Rectangular & No & I lateral & No & $\begin{array}{l}\text { Ventral, lenticular } \\
\text { bulbar scar }\end{array}$ & Fig Io, no. 3 \\
\hline 2009 & 690 & 9 & $36 \times 24.5 \times 7$ & Complete & Medial & Blade & Flint & Dark grey & $\mathrm{N}_{4} /$ & Recta & No & I central & No & None & \\
\hline 2009 & 694-I & 9 & $28 \times 21 \times 4.5$ & Complete & Medial & Blade & Flint & Dark grey & $\mathrm{N}_{4} /$ & Rectangular & No & I oblique & Yes & None & \\
\hline 2009 & 696 & 9 & $38 \times 29 \times 9$ & Complete & Proximal & Blade & Flint & Dark grey & $\mathrm{N}_{4} /$ & Rectangular & No & I lateral & Yes? & $\begin{array}{l}\text { Ventral, lenticular } \\
\text { bulbar scar }\end{array}$ & \\
\hline
\end{tabular}


Table 2 (cont)

\begin{tabular}{|c|c|c|c|c|c|c|c|c|c|c|c|c|c|c|c|}
\hline $\begin{array}{l}\text { क्रear of } \\
\overline{\bar{n}} \text { excavation }\end{array}$ & $\begin{array}{c}\text { Inventory } \\
\text { no. }\end{array}$ & Square & Measures (mm) & Condition & Part & Blank & Material & Colour & $\begin{array}{l}\text { Munsell } \\
\text { code }\end{array}$ & Shape & $\begin{array}{l}\text { Percussion } \\
\text { bulb }\end{array}$ & Arrises & $\begin{array}{l}\text { Use wear } \\
\text { traces }\end{array}$ & Notes & Figure \\
\hline$\frac{2009}{02009}$ & 700 & 9 & $28.5 \times 23.5 \times 7$ & Complete & Proximal & Flake & Flint & Black & $\mathrm{N} \mathrm{2.5/}$ & Rectangular & Yes, thinned & 2 oblique & No & None & \\
\hline 2009 & $718-1$ & 9 & $28.5 \times 24 \times 6$ & Complete & Medial & Blade & Flint & Dark grey & $\mathrm{N}_{4} /$ & Rectangular & No & I irregular & No & Lighter grey spots & \\
\hline$T_{2009}$ & 722 & 9 & $26 \times 23.5 \times 6$ & Complete & Medial & Blade & Flint & Very dark grey & $\mathrm{N}_{3} /$ & Rectangular & No & I transversal & No & None & \\
\hline 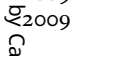 & 723 & 9 & (I5) $\times 19 \times 5.5$ & $\begin{array}{l}\text { Proximal } \\
\text { fragment }\end{array}$ & Medial & Blade & Flint & Black & $\mathrm{N}_{2.5} /$ & Rectangular & No & I central & No & None & \\
\hline $\begin{array}{l}3_{2009} \\
\text { ज. }\end{array}$ & 727-I & 9 & $30 \times 23 \times 5$ & Complete & Medial & Blade & Flint & Grey & $\mathrm{N}_{5 /}$ & Rectangular & No & I oblique & Yes & $\begin{array}{l}\text { Lighter grey spots, } \\
\text { metal residues? }\end{array}$ & \\
\hline क्مि2009 & 750 & 9 & $34 \times 28 \times 5$ & Complete & Medial & Blade & Flint & Grey & $\mathrm{N}_{5} /$ & Rectangular & No & 2 parallel & No & None & \\
\hline${ }^{2} 2009$ & 752 & 9 & $29 \times 26 \times 3$ & Complete & Medial & Blade & Flint & Very dark grey & $\mathrm{N}_{3} /$ & Rectangular & No & 2 parallel & No & None & \\
\hline 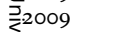 & $758-\mathrm{I}$ & 9 & $25 \times 22 \times 4$ & Complete & Medial & Blade & Flint & Very dark grey & $\mathrm{N}_{3} /$ & Rectangular & No & I lateral & No & None & \\
\hline 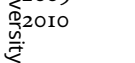 & 798 & 9 & $32.5 \times 25.5 \times 5.5$ & $\begin{array}{l}\text { Lower right corner } \\
\text { missing }\end{array}$ & Medial & Blade & Flint & Black & $\mathrm{N} 2.5 /$ & Rectangular & No & I oblique & Yes? & $\begin{array}{l}\text { Thinnings on the } \\
\text { ventral face }\end{array}$ & \\
\hline 梁 & 804-I & 9 & $34 \times 27 \times 5$ & Complete & Medial & Blade & Flint & Dark grey & $\mathrm{N}_{4} /$ & Rectangular & No & 2 parallel & No & $\begin{array}{l}\text { White cortex lower left } \\
\text { corner }\end{array}$ & \\
\hline$\tilde{n}_{201 \mathrm{II}}$ & 839 & 9 & $32 \times 25 \times 9$ & Complete & Medial & Blade & Flint & Unknown & Unknown & Rectangular & No & I central & No & $\begin{array}{l}\text { Yellowish red patina } \\
\text { (5YR4/6), metal } \\
\text { residue (pistol?) }\end{array}$ & Fig 7 , no. I \\
\hline
\end{tabular}




\section{ACKNOWLEDGEMENTS}

The authors would like to thank Drs G Trnka and M Brandl (Institute of Prehistory and Protohistory, Vienna University) for supplying the data regarding Monte Baldo (Trentino) flint outcrops, Avio gunflint production areas and Vienna Schloss Neugebäude gunflint caches; Mr G Chelidonio (Verona University) for the information regarding the Lessini Hills (Verona) flint and gunflint workshops; and Dr B A Voytek (Berkeley University) for the use-wear analyses. Special thanks are due to Dr T B Ballin (Bradford University) for his critical review of the manuscript and useful suggestions, and two anonymous Antiquaries fournal reviewers for their additional comments.

\section{BIBLIOGRAPHY}

Austin, R J 20I I. 'Gunflints from Fort Brooke: a study of some hypotheses regarding gunflint procurement', The Florida Anthropologist, 64 (2), 85-IO5

Ballin, T B 2012. "'State of art" of British gunflint research, with special focus on the early gunflint workshop at Dun Eistean, Lewis', Post-Medieval Archaeol, 46 (I), II6-42

Ballin, T B 2013a. 'Brief overview of gunflint forms from northern, eastern and southern Europe', Gunflints - Beyond the British and French Empires. Occasional Newsletter from an Informal Working Group, new ser, I (2), 4-I 2

Ballin, T B 2013b. 'Characterization of gunflint industries through attribute analysis a proposal', Gunflints - Beyond the British and French Empires. Occasional Newsletter from an Informal Working Group, new ser, 2, 4-I6

Ballin, T B 20I4a. 'Gunflints from Drottningen af Swerige (I745) and Concordia (I786)', Arms \& Armour, II (I), 44-67, <doi: I0.II79/174I6I24I4Z.00000000032> (accessed I2 Apr 2016)

Ballin, T B 20I4b. 'Identification of gunflints from shipwrecks', Vragmus.dk (the website of Sea War Museum Jutland), <http:// www.seawarmuseum.dk/cgi-files/mdmgfx/ file-I045-469778-1760.pdf > (accessed I6 Apr 2016)

Ballin, T B 20I4c. 'The investigation of Danish gunflint - methodological aspects', Gunflints Beyond the British and French Empires. Occasional Newsletter from an Informal Working Group, new ser, 2, 4-10

Barbieri, S, Avanzini, M and Grimaldi, S 2013. 'La selce nel bacino atesino meridionale: caratterizzazione e diffusione', Preistoria Alpina, 47, 27-37
Barfield, L H I994. 'The exploitation of flint in the Monti Lessini, northern Italy', in N Ashton and A David (eds), Stories in Stone, Lithic Stud Soc Occas Pap 4, 7I-83, Lithic Studies Society, London

Barnes, A S 1937. 'L'industrie des pierres à fusil par la méthode anglaise et son rapport avec le coup de burin tardenoisien', Bulletin de la Société préhistorique de France, 34 (7-8), 328-35

Beltrame, C 2007. 'Il Mercure: il relitto del brick del Regno Italico affondato nel I8I2 nella battaglia di Grado', in L Fozzati (ed), Caorle Archeologica. Fra mare, fiumi e terra, 137-46, Marsilio, Venice

Beltrame, C 2009. 'The excavation of the brig Mercure of the Regno Italico (I8I2). Why investigate a military vessel from the beginning of the r 9 th century?', in $\mathrm{R}$ Bockius (ed), Between the Seas. Transfer and Exchange in Nautical Technology. Proceedings of the Eleventh International Symposium on Boat Ship Archaeology, II, 249-57, Römisch-Germanischen Zentralmuseums, Mainz

Beltrame, C 2010. 'Elementi per un'archeologia dei relitti navali di età moderna. L'indagine di scavo sottomarino sul brick Mercurio', in S Medas, M D'Agostino and G Caniato (eds), Archeologia Storia Etnologia Navale. Atti del I convegno nazionale, Cesenatico - Museo della Marineria (4-5 aprile 2008), 55-6I, Edipuglia, Bari

Beltrame, C 2014. 'L'épave du brick Le Mercure (I8I2, Italie)', Archéothéma, 32, 62-5

Beltrame, C 2015. 'A tool assemblage from the brig Mercurio (I8I2): a caulker's storeroom?', Int $\mathcal{F}$ Nautical Archaeol, 44 (2), 423-50 
Beltrame, C and Gaddi, D 2002. 'Report on the first research campaign at the wreck of the Napoleonic brig, Mercure, Lignano, Udine', Int $\mathcal{F}$ Nautical Archaeol, 3I (I), 60-73

Bertoldi, F, Beltrame, C and Sisalli, C 2014. 'Human skeletal remains from the shipwreck of the brig Mercurio (I8I2)', in C Beltrame (ed), Archeologia dei relitti postmedievali, Archeologia Postmedievale, I8, I45-56, All'Insegna del Giglio, Florence

Bingeman, J M 2004. 'Gunlocks: their introduction to the Navy', <http://www. Invincible I758.co.uk/gun_flints.htm> (accessed I6 Apr 20I6)

Boudriot, J and Berti, H I98I. Brick de 24 Le Cygne I806-I808, A.N.C.R.E., Paris

Boudriot, J (with the collaboration of $\mathrm{H}$ Berti) 1992. L'artillerie de mer. Marine française I650-I850, A.N.C.R.E., Paris

Brandl, M 20I3. 'Characterisation of Middle European chert sources: a multi-layered approach to analysis', unpublished $\mathrm{PhD}$ thesis, University of Vienna

Chelidonio, G 1987. 'Le pietre del fuoco: metodo, problemi e prospettive di una ricerca interdisciplinare', Annali del Museo Civico di Rovereto, Sezione Archeologia, Storia e Scienze Naturali, 3, I I3-32

Chelidonio, G 1992. 'Sui sentieri delle pietre focaie: officine litiche storiche tra "foléndari" ambulanti e non', in R Maggi, R Nisbet and G Barker (eds), Atti delle Tavola Rotonda Internazionale Archeologia della Pastorizia nell'Europa Meridionale, 2, Rivista di Studi Liguri, 57, 233-5I

Chelidonio, G 2003. 'Le pietre del fuoco: un'archeo-storia durata fino a loo anni fa', Quaderni del Savena, 6, I25-36

Chelidonio, G 2013. 'Recent findings and observations on firestones and gunflints between craftsmanship, expedient strategies and warfare conditions', in F Lugli, A A Stoppiello and S Biagetti (eds), Ethnoarchaeology: current research and field methods, BAR Int Ser 2472, 36-4I, Archaeopress, Oxford

Cumming, E 2002. The Earl of Abergavenny: historical record and wreck excavation, Mibec Enterprises, Weymouth

Dal Santo, N 2004. 'Provenienza e utilizzo delle rocce silicee scheggiate del sito Neolitico di Palù di Livenza (Pordenone)', Atti della Società per la Preistoria e Protostoria della Regione Friuli-Venezia Giulia, I4, IO3-47 de Lotbiniere, S i984. 'Gunflint recognition', International fournal of Nautical Archaeology and Underwater Exploration, $\mathbf{1 3}$ (3), 206-9, <doi: Io.IIII/j.1095-9270.1984. tboi I9I. $x>$ (accessed I2 Apr 20I6)

de Vries, G and Martens, B J 2007. The Visser Collection. Arms of the Netherlands in the Collection of H L Visser. Volume I: Catalogue of Firearms, Swords and Related Objects, Special Interest Publicaties, Arnhem

Durst, J J 2009. 'Sourcing gunflints to their country of manufacture', Historical Archaeol, 43 (2), I9-30

Emy, J I978. Histoire de la pierre à fusil, Société d'Exploitation de l'Imprimerie Alleaume, Blois

Evans, A J I887. 'On the flint-knappers art in Albania', $\mathcal{F}$ Roy Anthropol Inst Great Britain and Ireland, I6, 65-8

Ferrari, A and Pessina, A 1996. Sammardenchia e $i$ primi agricoltori del Friuli, Arti Grafiche Friulane, Tavagnacco

Ginter, B 2009. 'New production site of gunflints for rifles in the region of Cracow', in I Gatsov (ed), Saxa loquuntur. In honorem 65th anniversari of Nikolai Sirakov, 345-59, Avalon, Sofia

Laplace, G 1964. Essay de Typologie systématique, Annali dell'Università di Ferrara, nuova serie, sezione I5, Paleontologia Umana e Paletnologia, I, Supplemento 2, Ferrara

Lovett, E 1877. 'Notices of gun flint manufactory at Brandon, with reference to the bearing of its processes upon the modes of flint-working practised in prehistoric times', Proc Soc Antiq Scotl, 2I, 206-I2

Mitchell, J I837. 'On the manufacture of gunflints', Edinburgh New Philosophical fournal, 22, 36-40

Orsi, P I886. 'Fabbriche veronesi di pietre da acciarino', Bullettino di Paletnologia Italiana, I2, 94-5

Penz, M and Trnka, G 2004. 'Ein ehemaliges Flintensteindepot aus dem Schloss Neugebäude in Wien', Fundort Wien. Berichte zur Archäologie, 7, 234-44

Roncal Los Arcos, M E, Martinez Fernandez, G and Morgado Rodriguez, A 1996. 'Las piedras de chispa: una producción lítica olvidada en España', Munibe, 48, IO5-23

Russell, J and Cohn, R 20I5. Timeline of the Adriatic Campaign, I807-I8I4, Transmedia Holding, Key Biscayne

Salmon, P I885. La fabrication des pierres à feu en France, Hennuyer, Paris 
Schleicher, C 1927. 'Une industrie qui disparait. La taille des silex modernes (pierres à fusil et à briquet)', Bulletin de la Société préhistorique de France, 24 (I0), 367-9

Skertchly, S B J I879. On the manufacture of gun-flints, the methods of excavating for flint, the age of Palaeolithic man, and the connection between Neolithic art and the gun-fint trade, Memoirs of the Geological Survey. England and Wales, HMSO, London

von Born, I E I790. 'Nachricht von den Flintensteinbrüken bey Avio in Walch Tyrol', in I E von Born and W H von Trebra (eds), Bergbaukunde Zweyter Band, 383-9, Verlag Georg Joachim Goeschen, Leipzig

White, S W I975. 'On the origin of gunspalls', Historical Archaeol, 9, 65-73

Whittaker, J C 200I. "“The oldest British industry": continuity and obsolescence in a flintknapper's sample set', Antiquity, 72, 382-90

Witthoft, J 1966. 'A history of gunflints', Pennsylvania Archaeologist, 36 (I-2), I2-49

Woodall, J N and Chelidonio, G 2006. 'Gunflint workshop traces in the Lessini Mountains (Verona, Italy): flintknappers and smugglers at the end of the Venetian Republic', in G Körlin and G Weisgerber (eds), Stone Age - Mining Age. Der Anschnitt (Proceedings of the VIII Flint Symposium held in Bochum on 13-I7 Sept 1999), I9, 213-26, Deutsches Bergbau-Museum, Bochum

Woodall, J N, Trage, S T and Kirchen, R W I997. 'Gunflint production in the Monti Lessini, Italy', Historical Archaeol, 3I, I5-27 